\title{
Land satellite imagery and integrated geophysical investigations of highway pavement instability in southwestern Nigeria
}

\author{
Omowumi Ademila ${ }^{1}$, Abel Idowu Olayinka ${ }^{2}$, Michael Adeyinka Oladunjoye ${ }^{3}$ \\ ${ }^{1}$ Adekunle Ajasin University, Department of Earth Sciences; Akungba-Akoko, Nigeria; \\ e-mail: omowumi.ademila@aaua.edu.ng (corresponding author); ORCID ID: 0000-0001-5177-1110 \\ ${ }^{2}$ University of Ibadan, Department of Geology; Ibadan, Nigeria; \\ e-mail: idowu.olayinka@ui.edu.ng; ORCID ID: 0000-0003-1834-5157 \\ ${ }^{3}$ University of Ibadan, Department of Geology; Ibadan, Nigeria; \\ e-mail: ma.oladunjoye@ui.edu.ng; ORCID ID:0000-0002-6162-4170
}

(C) 2020 Authors. This is an open access publication, which can be used, distributed and reproduced in any medium according to the Creative Commons CC-BY 4.0 License requiring that the original work has been properly cited.

Received: 14 November 2019; accepted: 17 July 2020; first published online: 31 August 2020

\begin{abstract}
The high global numbers of road accidents due to bad roads and the failure of other engineering structures have necessitated this study, particularly as road transport accounts for a higher percentage of cargo movement in African countries. The geophysical investigation was carried out on six failed and two stable sections along the Ibadan-Iwo-Osogbo highway to examine the geological factors responsible for highway failure in the area. A Landsat $\mathrm{ETM}^{+}$(Enhanced Thematic Mapper Plus) imagery of the study area and its environs was acquired and processed for lineaments analyses. Magnetic, Very Low Frequency Electromagnetic (VLF-EM) and electrical resistivity methods involving Schlumberger Vertical Electrical Sounding (VES) and 2-D imaging using a dipole-dipole array were utilized. Lineaments were identified across failed localities. Lateral magnetic variations in the near-surface geological materials characterized the study area. The 2-D VLF-EM models generated showed conductive zones corresponding to fractured zones of conductive clay materials within the basement rocks. Subgrade soils below the highway pavement along the failed sections are typical of incompetent clayey and sandy clay/clayey sand formations with resistivity values between $20-475 \Omega \cdot \mathrm{m}$. In comparison, the subgrade soil beneath the stable sections has moderate to high resistivity values of 196-616 $\Omega \cdot \mathrm{m}$. 2-D resistivity structures across the failed segments identified low resistivity water-absorbing clay and lithological contacts. Water absorbing, clay enriched subgrade soils and the identified near-surface linear conductive features are the major geologic factors, and poor drainage network resulted in the highway failure. Remote sensing and geophysical investigations of the geological sequence and structures underlying the highway should be carried out before construction to effectively complement the routine geotechnical studies to ensure the sustainability of road infrastructure.
\end{abstract}

Keywords: remote sensing, geophysical investigation, unstable highway sections, geological factors, subgrade

\section{INTRODUCTION}

Road transport is the most commonly used means of transportation in Africa. Unfortunately, the rate at which these roads, including highways, have failed has increased tremendously in recent times, and this calls for immediate attention. Road transport accounts for over $80 \%$ of all freight and passenger movements in Afri$\mathrm{Ca}$, and there are no signs that the position will change in the foreseeable future (African Development Bank 2003). In Africa, roads are links to 
accessing education, health, and social services and also help in the smooth transfer of policies from central governments to different communities in the areas with efforts to reduce poverty and hunger. Nigeria is among the countries with the highest records of road accidents in the world, contributing one-fifth of the 3,500 daily road accidents in the world (Guardian News Paper 2012). The use of remote sensing in transportation research is becoming an essential and economically advantageous area of exploration in the identification and analysis of pavement defects and distress (Schnebele et al. 2015). Most structural failures can be attributed to inadequate knowledge of the physical parameters and geological features governing the competency of the soil materials used for construction. A lineament analysis using a Landsat Thematic Mapper (TM) dataset of the Golmarmara (Manisa) region was performed by Kavak \& Cetin (2007) to identify linear geological features that could be attributed to palaeotectonic and/or neotectonic structures. They emphasized that extensive NE and ENW trending lineament systems have developed in the region, and most of the ENW-SSE trending lineaments are associated with the recent normal faulting of the western Anatolia after the middle Miocene period (5.3-23 Ma). The geophysical investigation has found useful applications in shallow engineering and foundation studies (Sharma 1997, Ademila 2015). The collapse of concealed subsurface geological structures and other zones of weakness controlled by regional fractures and joint systems, combined with silica leaching, has led to rock deficiencies and are known to contribute to the failures of highways and rail tracks (Nelson \& Haigh 1990). Site investigation using geophysical methods is more beneficial since it provides detailed information about the subsurface, which in turn determines how feasible an area would be in terms of the erection of structures that will stand the test of time (Oluwafemi 2012). Geophysical methods are useful in determining a variety of the physical properties of soil and rock. Electrical Resistivity (ER), Seismic Refraction, Electromagnetic (EM), Magnetic, and Ground Penetrating Radar are used singly or in combinations for engineering site investigation. These geophysical methods are used in the determination of depth to bedrock, structural mapping, and the evaluation of subsoil competence. Geophysical prospecting methods provide detailed information about the relevant Earth material properties required in evaluating the capability of subsurface soil for highway construction (Olorunfemi et al. 2010). Olayinka et al. (2007) used an integrated geophysical investigation to determine the causes of structural failures in Nigeria. They reported that inferior subbase materials and poor compaction during construction account for the failure of rigid pavements in Nigeria. Ademila (2015) revealed that thorough and detailed geophysical/geotechnical investigation acts as a necessary task needed to be carried out before the construction of any engineering structure as it guarantees post-construction stability. Remote sensing and integrated geophysical data will provide an effective way of assessing the causes of the continuous failure of the road transportation infrastructure network in the Africa region. This is because these developing countries have lost precious infrastructure worth billions of dollars through road pavement failures. This research attempts to find out the cause(s) of persistent pavement failure along Ibadan-Iwo-Osogbo Highway by integrating satellite imagery of the study area and its environs with geophysical investigation. This serves as a post-construction study to establish a geological basis and any other reasons for the instability of the road pavement and proffering lasting remediation measures.

\section{LOCATION \\ AND GEOLOGICAL SETTING OF THE STUDY AREA}

The Ibadan-Iwo-Osogbo highway is located in southwestern Nigeria. It is situated within the geographical co-ordinates of: latitudes $\mathrm{N}^{\circ} 37.50^{\prime}$ - $\mathrm{N}^{\circ} 48.18^{\prime}$ and longitudes $\mathrm{E} 4^{\circ} 10^{\prime}-\mathrm{E} 4^{\circ} 30^{\prime}$ or between N845000 - N862735 m and E628638 E665459 $\mathrm{m}$ in the Universal Traverse Mercator (UTM) Minna Zone 31 co-ordinates. The road is about $86 \mathrm{~km}$ long and trends approximately southwest-northeast (Fig. 1). It is a major and 
important access road linking many states in southwestern Nigeria, and this contributes to the heavy traffic along the highway. Along this major highway are linear settlements. The drainage pattern of the study area is dendritic with rivers like the Oba, the Osun, the Eyinle, the Orufu, the Aro, the Awon, and many other tributaries. They generally flow southwards to join the coastal lagoon. Streams flow through a north-south direction, parallel or sub-parallel to the strike of the Basement Complex rocks; its tributaries form a dense dendritic drainage pattern. In the study area, the high rate of annual rainfall is primarily responsible for the recharge of the groundwater. In the basement complex area, groundwater is contained within the weathered and/or fractured/jointed basement columns. The aquifer units in the area and other similar basement complex environments are believed to be principally derived from the weathered rocks (Olayinka \& Olayiwola 2001). The drainage pattern is dendritic and surface water percolates down through the fractured and weathered zones. Hand-dug wells are the primary source of water for the residents of the area, and in most cases, the weathered regolith is the major aquifer unit for these wells. The total depth of the hand-dug wells in the region ranges between 1.3$13.3 \mathrm{~m}$. This, therefore, suggests that the water table in the area is relatively shallow, and this might contribute to the failure of the road.

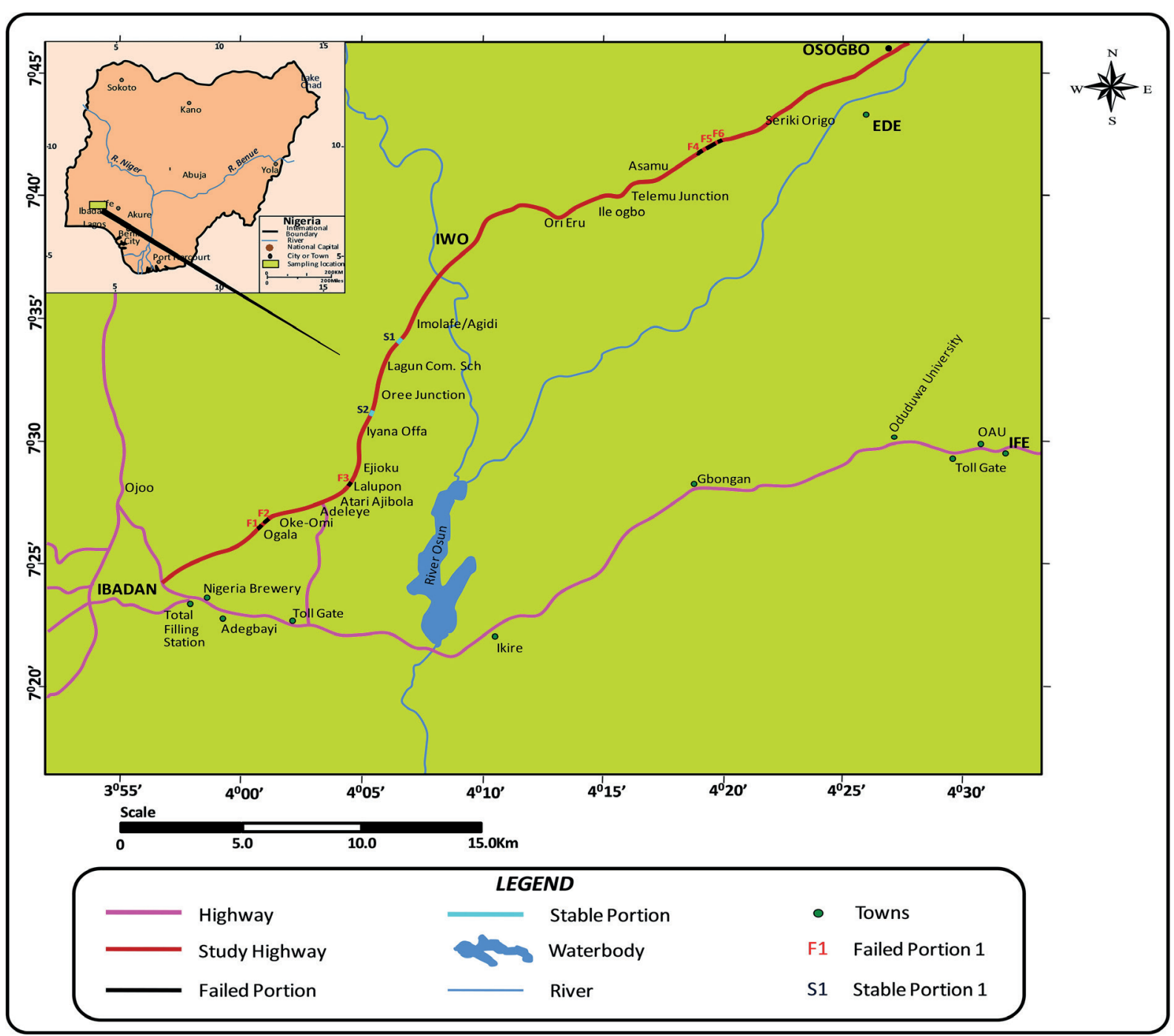

Fig. 1. Location map of the study area showing the failed and stable sections of the road 


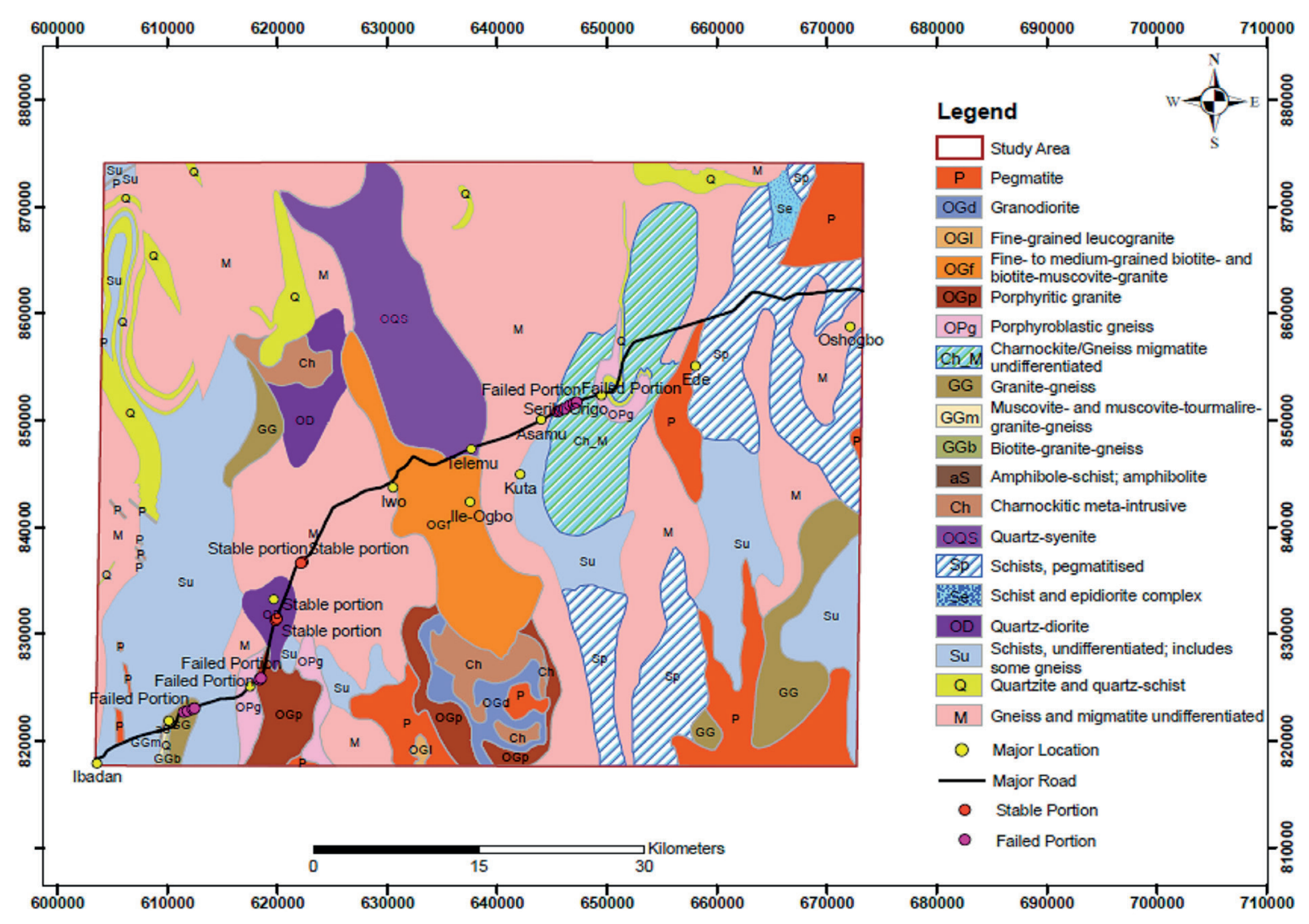

Fig. 2. Geological map of the area around Ibadan-Iwo-Oshogbo Highway showing the stable and failed sections of the road (modified after Nigeria Geological Survey Agency 2009)

Geologically, the study area is underlain by the Precambrian Basement Complex rocks of Nigeria. The Basement Complex rocks comprise gneisses and migmatites with supracrustal relics, which are Archean (c. $2700 \mathrm{Ma}$ ) to Proterozoic (c. $2000 \mathrm{Ma}$ ) in age Annor (1995). The Basement Complex rocks of Nigeria forms a part of the African Crystalline Shield, which occurs within the Pan-African mobile belt that lies between the West African and Congo Cratons and South of the Tuareg Shield which were affected by the Pan-African orogeny (Oyawoye 1972, Woakes et al. 1987). The Basement Complex of southwestern Nigeria is located in a triangular portion of the Nigerian basement, an extension of the Dahomeyide Shield of the West African Craton. Rocks of the region include the Migmatite-Gneiss Complex (MGC) that is characterized by (a) grey foliated gneiss, (b) ultramafic rocks, and (c) felsic component comprised of pegmatite, aplite and granitic rocks
(Rahaman 1981). The MGC in southwestern Nigeria is affected by three major geotectonic events ranging from Early Proterozoic of $2000 \mathrm{Ma}$ to Pan-African events of $\sim 600 \mathrm{Ma}$ (Ajibade \& Fitches 1988, Oyinloye 2011).

The highway cuts across some rock units, namely gneiss/migmatite to schist pegmatite, quartzo-syenite, charnockite, pegmatite, meta-intrusives, and fine-medium grained granite (Fig. 2). Gneisses are migmatized in places and characterized by predominantly medium-sized grains with well-defined bands of quartzo-feldspathic minerals alternating with ferromagnesian minerals Olayinka et al. (1999).

\section{MATERIALS AND METHOD}

\section{Satellite imagery analysis}

Medium-resolution satellite Landsat imagery has been widely used for urban change detection 
(Kadhim et al. 2016). A digitized map of the study area and its environs on a 1:100 000 scale topographic quadrangles was used to extract the lineaments through several false colour composites of bands 3, 4, and 5 of a Landsat TM dataset. Pre-processing data reduction (haze reduction) was carried out on a Landsat Thematic Mapper (TM) image dataset. This enhanced the signal to the atmospheric noise ratio of the image. The extracted lineaments were classified by drawing rose diagrams, which discerned the orientation and frequency of occurrence of the extracted lineaments. The extracted lineaments were converted to vector formats in an ArcGIS 10.2.1 environment.

\section{Geophysical measurements}

Six major failed sections and two stable sections ranging in length $200-730 \mathrm{~m}$ with various lithological units were studied (Fig. 1). The geophysical investigation involved electromagnetic, magnetic, and electrical resistivity methods. Each traverse was established at each of the localities parallel to the road pavement and was made to cut across the sections of the highway. The VLF-EM method detects electrical conductors by utilizing radio signals in the $15-25 \mathrm{kHz}$ range that are used for military communications. It is useful for detecting long, straight electrical conductors, such as moderate to steeply dipping water-filled fractures or faults. The VLF instrument compares the magnetic field of the primary (transmitted) signal to that of the secondary signal (induced current flow within the subsurface electrical conductor). In the absence of subsurface conductors, the transmitted signal is horizontal and linearly polarized. The anomaly associated with a conductor exhibits a crossover. As with other frequency domain electromagnetic systems, both the in-phase (real or tilt-angle) and the out-of-phase (imaginary, ellipticity, or quadrature) components are measured. VLF-EM measurements were taken with ABEM Wadi portable VLF-EM equipment with a station to station interval of $5 \mathrm{~m}$. Data were collected along the traverses, and data filtering was carried out to enhance the signal and make tilt-angle crossovers easier to identify. The real and quadrature components of the VLF-EM were measured at each station, but the real component data, which are usually more diagnostic of linear features, were processed for a qualitative interpretation. Data filtering was carried out to enhance the signal and make tilt-angle crossovers easier to identify. The raw real VLF-EM data were converted into filtered real data in which anomaly inflections appear as positive peak anomalies and false VLF anomaly inflections as negative anomalies of the profile (Reynolds 1997). The filtering was done with the use of an in-built filtering program in the ABEM WADI equipment and software known as KH Filt version 1.0 (Karous \& Hjelt 1983, Pirttijärvi 2004). The VLF-EM results were presented as profiles and inverted pseudosections obtained by using the KH Filt software. The field data are measures of the amplitude response of earth materials to the primary electromagnetic field, which indicate the degree of conductivity/resistivity of the earth materials. The raw real data of the VLF-EM were filtered using Karous-Hjelt filter factor (Karous \& Hjelt 1983, Pirttijärvi 2004):

$\mathrm{F} 1=(\mathrm{M} 4+\mathrm{M} 3)-(\mathrm{M} 2+\mathrm{M} 1)$

$\mathrm{F} 2=(\mathrm{M} 5+\mathrm{M} 4)-(\mathrm{M} 3+\mathrm{M} 2)$

where F1 and F2 are 1st and 2nd filter factors respectively, and M1, M2, M3, M4 and M5 are measurements taken at station 1,2, 3, 4 and 5 respectively, and F1 and F2 are plotted at the middle of stations 2 and 3, and middle of stations 3 and 4 respectively and so on (Reynolds 1997). The real and filtered real components were plotted against station positions using 'KHFFILT' software version 1.1a. A 2-D inversion of the real component data was carried out using the same software. Interpretations were done normally by considering the high amplitude signal, which is diagnostic of weathered or fractured zones. Qualitative interpretations, making use of the Karous-Hjelt $(\mathrm{KH})$ filter processing software package, display negative amplitude responses as being indicative of resistive bodies and positive amplitude responses for conductive materials.

The magnetic method measures variations in the Earth's magnetic field caused by changes in the subsurface geological structure or the differences in near-surface rocks' magnetic properties, 
which are known as susceptibility or remanence, which causes small changes in the Earth's magnetic (Geomagnetic) field strength and direction. The purpose of the magnetic survey in this study is to investigate subsurface geology on the basis of anomalies in the Earth's magnetic field resulting from the magnetic properties of the underlying rocks. The ground magnetic survey involved the measurement of total field component of the Earth's magnetic field with the GSM 19T Proton Precession Magnetometer (GEM System) at $5 \mathrm{~m}$ intervals along each of the traverses. The closely spaced stations adopted for the magnetic survey allow high resolution of near-surface sources to be obtained. Two magnetic measurements with sensor heights at $1.5 \mathrm{~m}$ were taken per station, and the mean of the magnetic measurements was obtained for each observed station. A set of readings (twenty different readings) were taken at an established base station close to each traverse before the commencement of measurement and immediately after the traverse had been occupied to allow for diurnal and offset corrections. The diurnal correction removes the diurnal variations from the mobile data so that the anomalies can be better appreciated. Corrected magnetic data were plotted against station positions and presented as profiles.

In the electrical resistivity survey, artificially generated electrical currents are passed into the ground, and the resulting potential differences are measured at the surface. The technique explores the fact that there is a large contrast in the resistivity of ore bodies and their surrounding host rocks. Two galvanized electrodes are used to supply a controlled electrical current to the ground. The lines of current flow adapt to the subsurface resistivity pattern so that the potential differences between the two points on the ground surface can be measured using a second pair of electrodes. Deviations from the pattern of potential differences expected from a homogenous ground provide information on the form and electrical properties of subsurface inhomogeneities. The instruments introduce controlled current into the ground through metal electrodes and measures the resulting potential difference between the potential electrodes, displaying the internally computed resistance value and/or the current $[\mathrm{A}]$ and potential $[\mathrm{V}]$. Thus, the output resistances are average values over a number of cycles from each of these resistances; the apparent resistivity for a particular spread length is computed using the relevant geometric factor $(\mathrm{K})$. The electrical resistivity method utilized two field techniques: Vertical Electrical Sounding (VES) involving the Schlumberger configuration and 2-D electrical imaging using a dipole-dipole array. The Schlumberger VES entails vertical probing of the subsurface while the dipole-dipole survey was adopted to determine the lateral and vertical variation in apparent ground resistivity beneath each specific traverse. Sounding stations were established at $25 \mathrm{~m}$ intervals along each traverse. Seventy-six (76) sounding stations were occupied along the failed sections, while eighteen (18) along the stable sections. The half electrode spacing $(\mathrm{AB} / 2)$ was varied between 1-150 m. The apparent resistivity measurements were plotted against electrode spacing on bi-logarithmic graph sheets. Partial curve matching was carried out for the quantitative interpretation of the sounding curves. The results of the curve matching (layer resistivities and thicknesses) were used as starting model parameters for 1-D forward modeling using Resist version 1.0 (Vander Velper 2004). The VES interpretation results were used for the construction of geoelectric sections along the various sections. In a dipole-dipole array, four electrodes are also used but they do not necessarily occupy a position along a common line. The current dipole is separated from the potential dipole, the distance in-between each dipole is short while the separation between the two pairs is considerably large. 2-D resistivity data acquisition was carried out with the dipole-dipole array. The inter-electrode spacing of $5 \mathrm{~m}$ was adopted. The apparent resistivity values were presented as pseudosections. 2-D inversion of the dipole-dipole data was carried out using the Dipro for Windows (2001) software. The software automatically determines a 2-D resistivity model of the subsurface for the obtained data. The measured apparent resistivity data were inverted to create a model for the subsurface resistivity using an iterative smoothness-constrained least square inversion. An acceptable model is normally arrived at within five iterations. This scheme needs no previous knowledge of the subsurface; the initial guess model is constructed directly from the field measurements. 


\section{RESULTS AND DISCUSSION}

\section{The geological lineament map}

Lineaments assume to reflect subsurface phenomenon and can generally be equated with structural elements such as folds, fractures, faults, and joints (Viljoen et al. 1983). Figure 3A shows the lineament map of the study area. Four major structural trends are represented in the area. One set of the lineaments trend N-S direction, the second NNW-SSE direction, the third E-W, and the fourth NW-SE direction (Fig. 3B). It is suspected that such linear features may be one of the factors responsible for the continuous failure of the failed sections of the highway.

$\mathrm{A}$

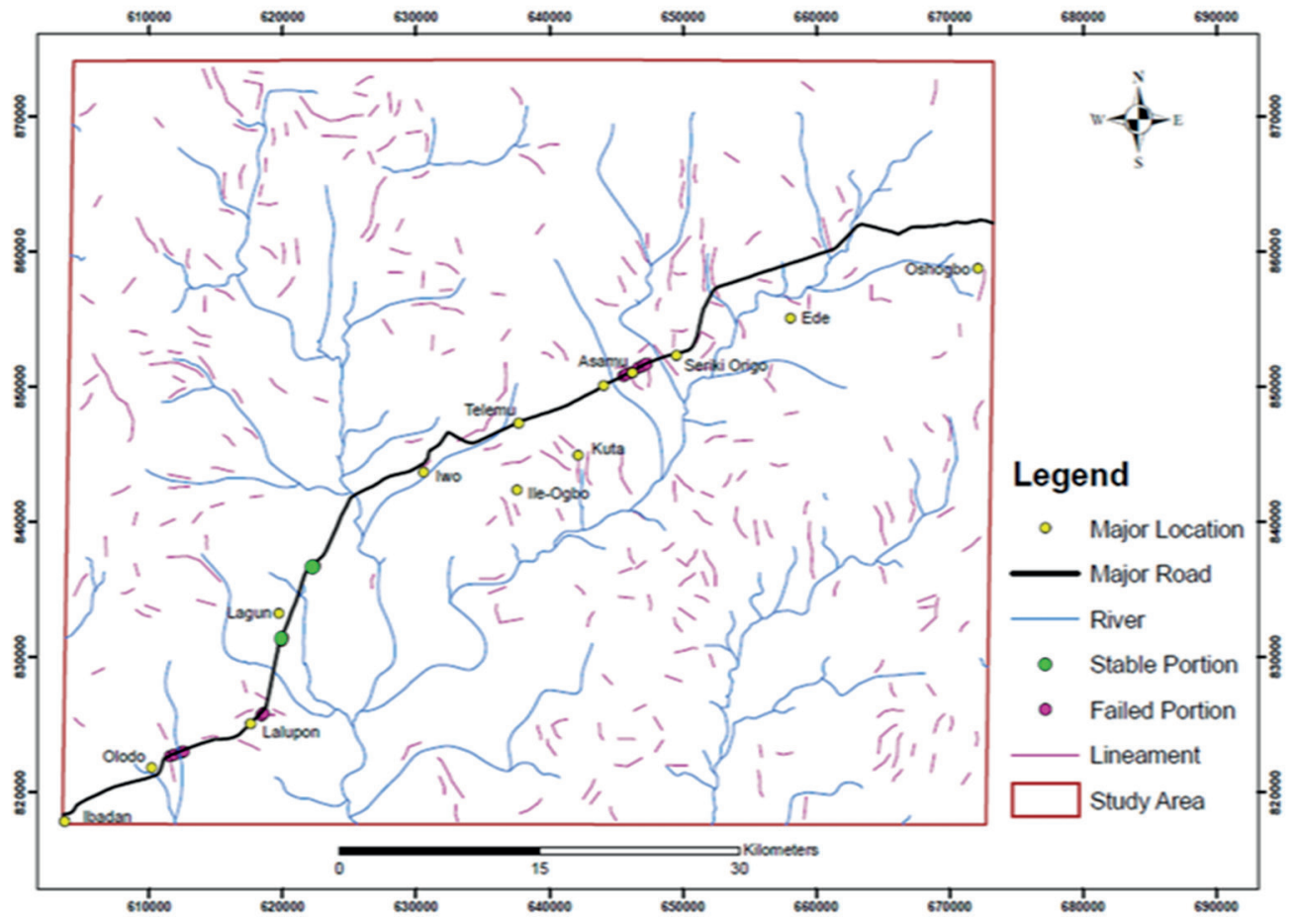

$\mathrm{B}$

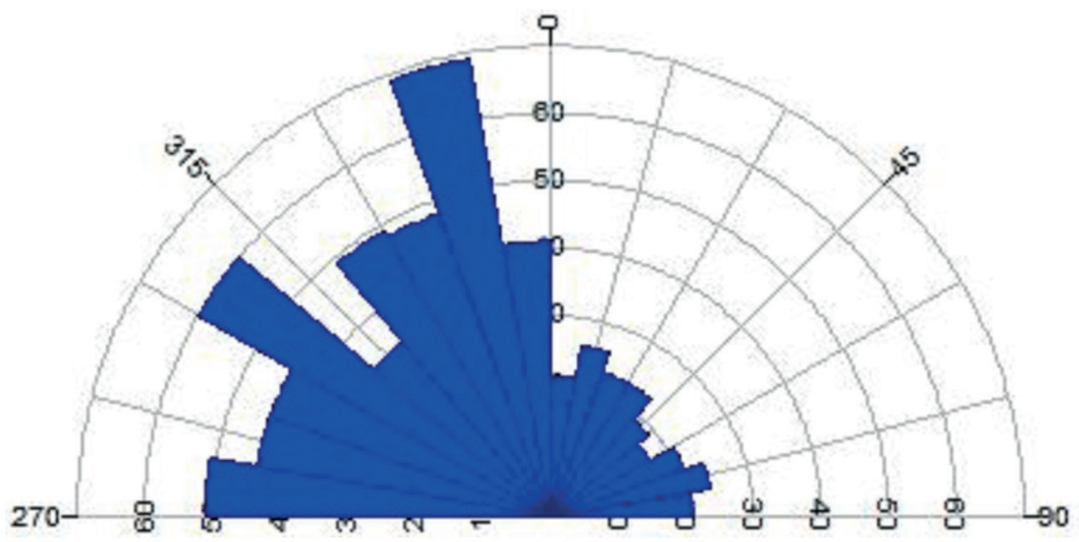

Fig. 3. Lineament map of the study area (A); rose diagram showing the lineament trends (B) 


\section{Geophysical investigations}

The VLF-EM technique is an effective reconnaissance geophysical tool for mapping geoelectric features especially the electrically conductive features such as fault zones, which tend to be more conductive than the surrounding bedrock or host rock. That is, it is very effective for locating zones of high electrical conductivity. It is also useful in mapping other conductive geological units which include moist, clayey or fine grained soils which are more conductive than dry, sandy or coarse grained soils. Its relative increase in the speed of operation and low cost of survey makes it suitable to work through resistive superficial layers. It has the ability to detect anomalies at a relatively low level of conducting contrast. It also improves lateral resolutions compared with conventional resistivity. The magnetic method is relatively cost effective and time saving. Data collection is fast, inexpensive and requires a smaller field crew. The magnetic variations in the subsoil materials that underlie the study area indicate varying bearing capacities and thus result in an unequal yielding capacity to the weight of structures that lie on it, hence, the failure that characterized the area. The electrical resistivity methods have found wide applications in civil engineering studies. They are convenient, non-destructive method of determining the depth to bedrock for foundation purposes, as bedrock is usually more resistive than overburden. Resistivity methods provide information on the degree of saturation of subsurface materials. They are used to indicate the presence of potentially unstable ground conditions. The methods also provide valuable information on geological structures, lithologic units and subsurface water resources without the large cost of an extensive programme of drilling. Qualitative interpretation is straight forward. Quantitative modeling is possible using the master curves and its auxiliary charts and the computer software. The models provide accurate estimates of depth, thickness and electrical resistivity of subsurface layers and other possible interpretations.

The results obtained from this study are presented as maps, profiles, pseudosections, depth sounding curves, geoelectric sections, and 2-D resistivity structures. The varying amplitude of the VLF profile represents changes in the conductivity of subsurface earth materials, while the pseudosection represents the conductivity changes along with the profiles with respect to depth. The positive peak amplitude of the filtered real values indicates the presence of conductive bodies. Thus, the disposition of the conductive features identified on the pseudosections is attributed to fractures, faults, and lineaments structures.

\section{Vertical electrical sounding}

The resistivity sounding curves obtained from the study area vary from 3 to 5 layers, with the HA curve type dominating. Ten curve types have been identified in all the locations of the area. These include the A, H, AA, HA, HK, KH, HAA, HKH, AKH, and KHA types which are typical of basement curves (Fig. 4 on the interleaf). The summary of the typical VES curves obtained in the study area is given in Table 1 . The curve types can be good indicators of the stability of the highway pavement, especially the A, AA, and $\mathrm{KH}$ types, because of their increasing competence with depth. The VES interpretation results were used for the construction of geoelectric sections along the various sections.

Table 1

Interpretation of selected sounding curves

\begin{tabular}{|c|c|c|c|c|c|c|c|c|c|c|}
\hline \multirow{2}{*}{$\begin{array}{c}\text { VES } \\
\text { no. }\end{array}$} & \multicolumn{4}{|c|}{ Resistivity $\boldsymbol{p}[\mathbf{\Omega} \cdot \mathbf{m}]$} & \multicolumn{4}{c|}{ Thickness $\boldsymbol{h}[\mathbf{m}]$} & \multirow{2}{*}{ Curve type } \\
\cline { 2 - 11 } & $p_{1}$ & $p_{2}$ & $p_{3}$ & $p_{4}$ & $p_{5}$ & $h_{1}$ & $h_{2}$ & $h_{3}$ & $h_{4}$ & \\
\hline 1 & 96 & 799 & 28 & 1198 & - & 0.5 & 1.2 & 6.5 & - & KH \\
\hline 19 & 103 & 33 & 9867 & - & - & 0.8 & 3.6 & - & - & H \\
\hline 28 & 222 & 128 & 783 & 499 & $\infty$ & 0.9 & 2.2 & 5.4 & 37.5 & HKH \\
\hline 29 & 61 & 604 & 10095 & - & & 1.3 & 6.0 & - & - & A \\
\hline 37 & 101 & 40 & 7352 & $\infty$ & - & 1.4 & 7.9 & 15.0 & - & HK \\
\hline 39 & 131 & 391 & 68 & 1815 & $\infty$ & 0.7 & 1.7 & 7.2 & 18.6 & KHA \\
\hline 40 & 178 & 57 & 123 & 699 & $\infty$ & 1.0 & 1.6 & 12.2 & 14.6 & HAA \\
\hline 59 & 118 & 679 & 2666 & $\infty$ & - & 1.3 & 7.5 & 15.2 & - & AA \\
\hline 63 & 144 & 280 & 3342 & 814 & $\infty$ & 0.9 & 1.6 & 4.8 & 24.1 & AKH \\
\hline 82 & 230 & 69 & 213 & 1900 & - & 0.9 & 2.7 & 17.2 & - & HA \\
\hline
\end{tabular}



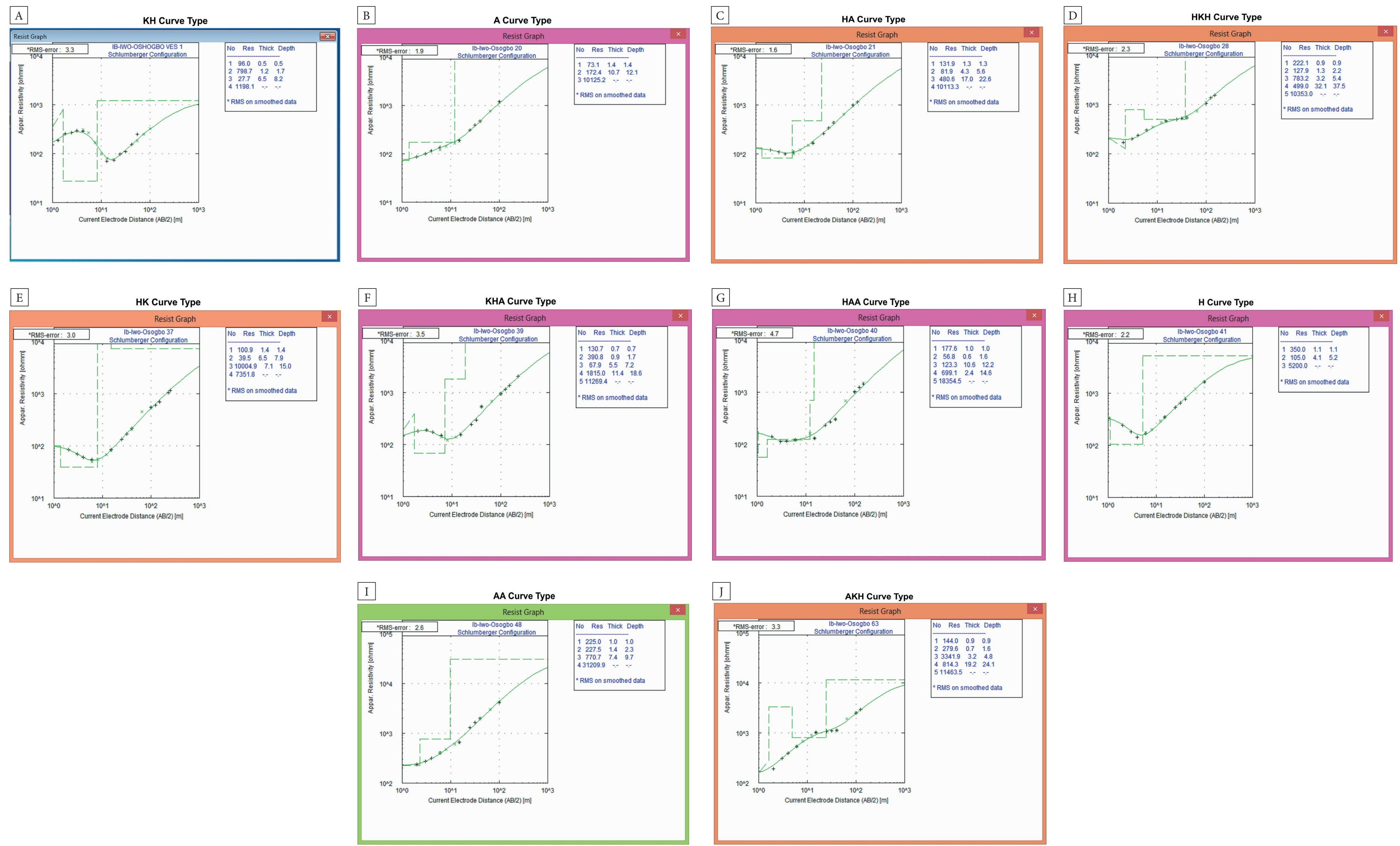

Fig. 4. Typical curve types obtained from the study area: A) KH curve type; B) A curve type; C) HA curve type; D) HKH curve type; E) HK curve type; F) KHA curve type; G) HAA curve type; H) H curve type; I) AA curve type; J) AKH curve type 
The Karous-Hjelt filter 2-D model sections display pictorial distribution of subsurface geologic features. Major conductive features of varying degrees of conductivity trending in different directions were delineated on the sections. The identified conductive zones (green to red colour in Figs. 5A, 6A, 7A, 8A, 9A, 10A, 11A, 12A) were used to delineate the presence of near-surface linear features interpreted as fault/fracture zones, weathered basement and sheared zones within the bedrock. These conductive zones tend to influence the failure of the road pavement. The conductors are indicated by the positive peak of the filtered values (green to red colour codes) and are interpreted as potential fractures, faults, lithologic contacts, sheared zones and weathered basement. The subsurface conductive features (F-F', F1-F1'F1", F2-F2' ... F14-F14') as shown in Figures 5A, $6 \mathrm{~A}, 7 \mathrm{~A}, 8 \mathrm{~A}, 9 \mathrm{~A}, 10 \mathrm{~A}, 11 \mathrm{~A}, 12 \mathrm{~A}$ are characteristics distinctive zones of weakness usually responsible for rock instability in a basement complex terrain precipitating the failure of the highway. Although, these conductive zones are relevant in the groundwater development of an area as they serve as potential sites for groundwater abstraction, they are the possible causes of foundation based failures of civil engineering structures as they expose the foundation to the ingress of water with resultant reduced strength/load bearing capacity of the subsoil. Corrected magnetic data were plotted against station positions and presented as profiles (Figs. 5B, 6B, 7B, 8B, 9B, 10B, 11B, 12B). The plots of the corrected magnetic data against the station positions produce profiles that can be qualitatively interpreted to provide information on the subsurface geology of the study area. The inflection points are diagnostic of structural changes such as geological boundaries, basement ridges, and depressions, fractures, and faults in the subsurface. Generally, the magnetic highs represent regions of magnetic minerals such as metamorphic or igneous rocks while magnetic lows represent regions with linear geologic features. However, several anomalies with considerable variations in magnetic field intensities have been identified at varying positions along with the profiles. These anomalies are essentially characterized by peaks and troughs that are suspected of indicating magnetic sources in the subsurface (Reynolds 1997). These magnetic sources could be related to fractures/ faults and other weak zones that are responsible for the continuous failure of the overlying road structure. Typical resistivity soundings results obtained after the processing are shown in Figure 4 (on the interleaf) and Table 1 . The results obtained from the quantitative interpretation of the sounding curves were used to generate the geoelectric sections (Figs. 5D, 6D, 7D, 8D, 9D, 10D, 11D, 12D). The geoelectric sections represent the geologic sequence mapped with respect to depth. It shows the lateral continuity of each delineated sequence across the VES stations. There is a relationship between electrical resistivity of earth materials and the subsurface capacity to sustain an engineering structure. Results from the electrical resistivity method revealed the pattern of resistivity variations within the study area. Engineering competence of the soil can be evaluated from layer resistivity because, the higher the layer resistivity value, the higher the competence of a layer.

\section{Failed section 1}

The VLF-EM 2-D model shows patches of relatively conductive features between $25-75 \mathrm{~m}$, $175-225 \mathrm{~m}$, and around $250 \mathrm{~m}$ (Fig. 5A). Areas associated with conductivity, as reflected in the pseudosection, are considered to be zones of weaknesses such as fractures, faults, and lineaments. The magnetic anomalies are located between $50-80 \mathrm{~m}, 160-200 \mathrm{~m}$, and $250-300 \mathrm{~m}$ (Fig. 5B). The magnetic anomalies observed in the study area are assumed to have resulted from the basement as well as magnetic materials within the fractured/faulted zones relative to the fresh bedrock. The causative bodies are generally of a significant width. These magnetic variations in the subsoil materials that underlie the study area have varying bearing capacities and thus may result in an unequal yielding capacity to the weight of structures that lie on it, hence, the failure that characterized the area (Ademila 2017). The magnetic anomaly zones correlate significantly with the EM-VLF anomalous zones along the failed section. The 2-D dipole-dipole resistivity structure shows that the overburden is generally thick $(>5 \mathrm{~m})$ in all places except between the distance of 0 and $30 \mathrm{~m}$. It, however, identifies near-verti$\mathrm{cal} /$ vertical low resistivity features having a depth 
extent of up to $20 \mathrm{~m}$ typical of lineaments/fractures and buried channels with surface expressions at $35-50 \mathrm{~m}, 75-120 \mathrm{~m}$ and $175-300 \mathrm{~m}$ from the Ibadan end of the section (Fig. 5C). The failed section is characterized by four geoelectric layers. These include the topsoil, the weathered layer, the fractured basement, and the crystalline basement rock. The failed section of the road recorded low topsoil resistivity of $20-224 \Omega \cdot \mathrm{m}$. The weathered layer resistivity values range $11-38 \Omega \cdot \mathrm{m}$, and the thickness ranges $1.2-9.0 \mathrm{~m}$ (Fig. 5D). These low resistivity values observed beneath this unstable section are typical of clay enriched water-absorbing substratum. The failure along this section of the road is apparently precipitated by differential settlement induced by the clayey substratum.

A
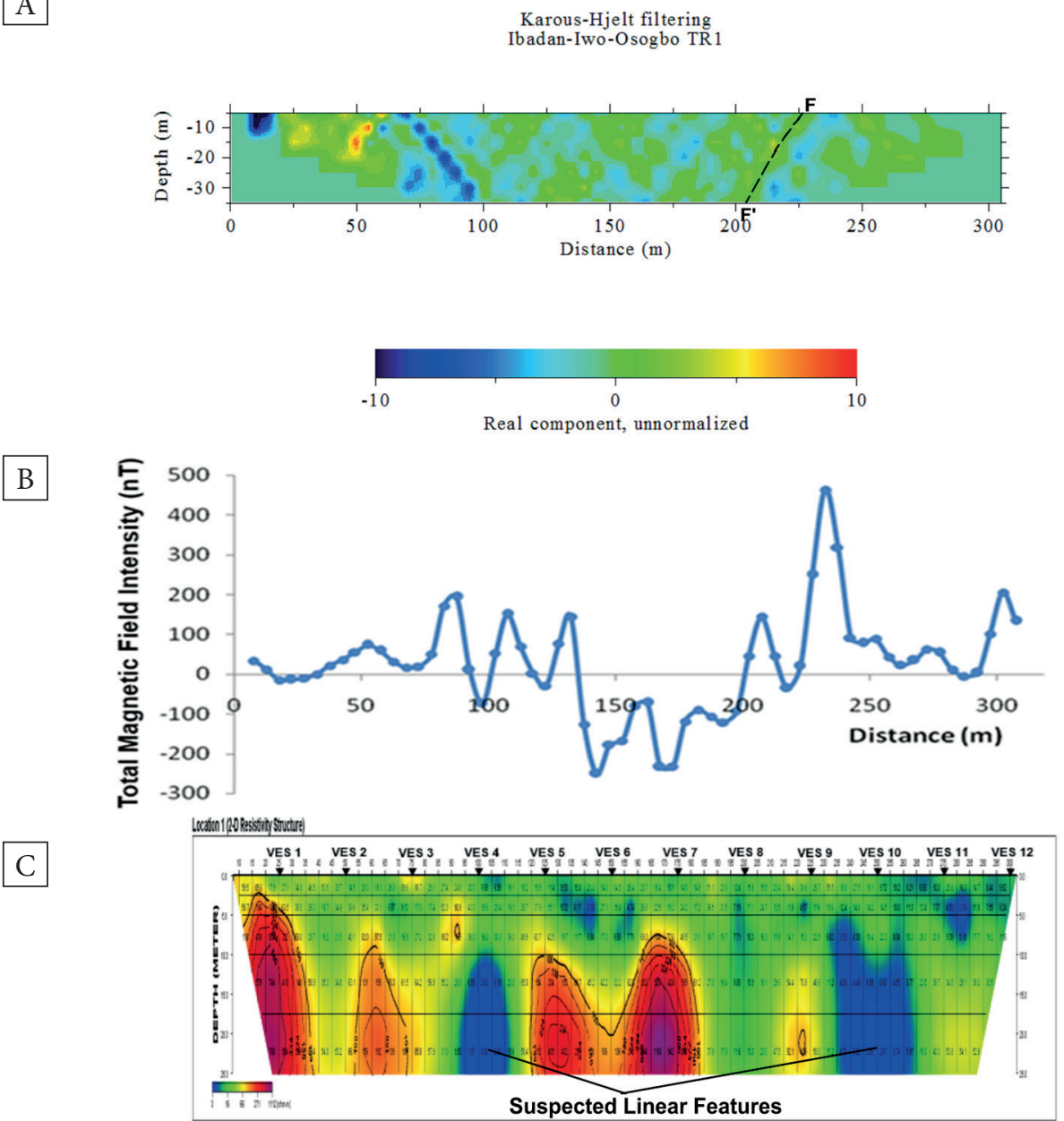

$\mathrm{D}$

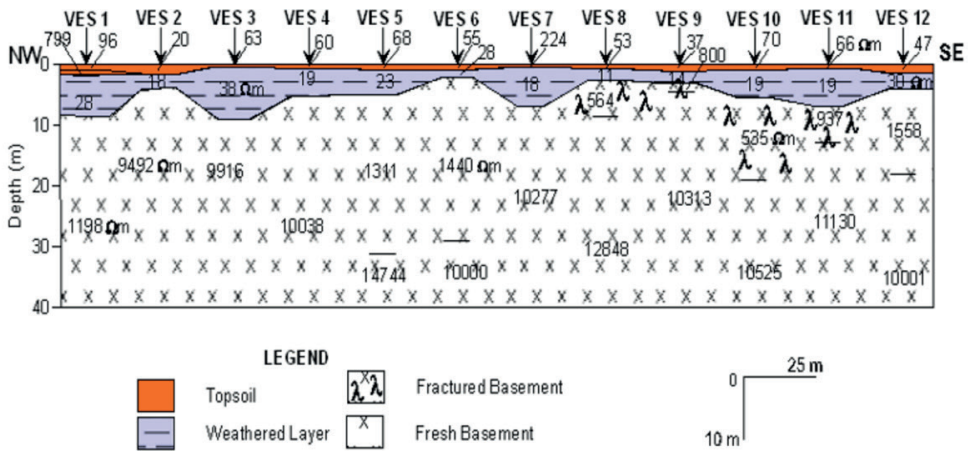

Fig. 5. VLF-EM 2-D inverted model (A); total magnetic field intensity profile (B); 2-D subsurface resistivity structure (C) and geoelectric section along failed section $1(D)$ 


\section{Failed section 2}

Failed section 2 shows anomalous VLF-EM signatures at various locations along the road. The Karous-Hjelt filter 2-D inversion model (Fig. 6A) gives the spatial distribution of subsurface geological features. The conductive features between $20-35 \mathrm{~m}$ and $65-185 \mathrm{~m}$ (indicated by a green to red colour) along the failed section are interpreted as possible fractures beneath subsurface. These conductive zones are probably indicative of fractures/ faults or other weak zones in the form of lithological contact or clayey overburden. These suspected fractures are observed to be dipping in northwest-southwest and northeast-southwest directions.

$\mathrm{A}$
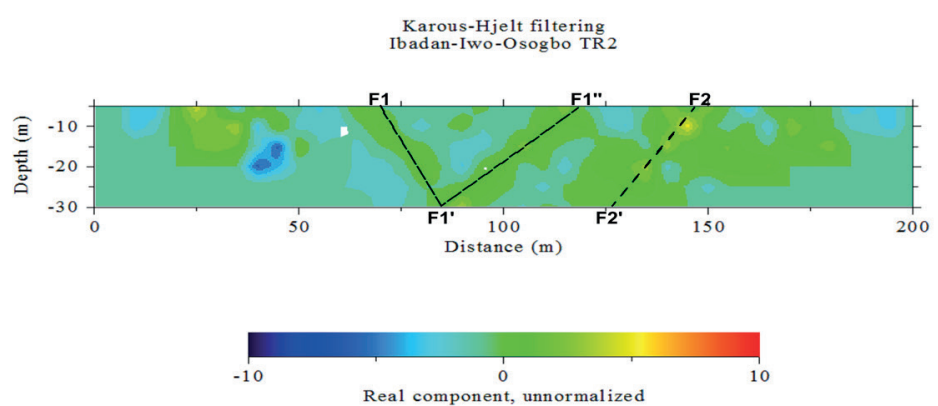

$\mathrm{B}$

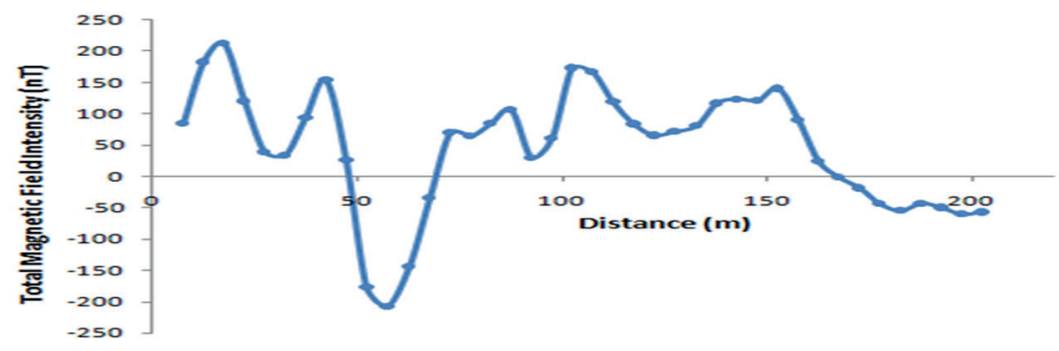

$\mathrm{C}$
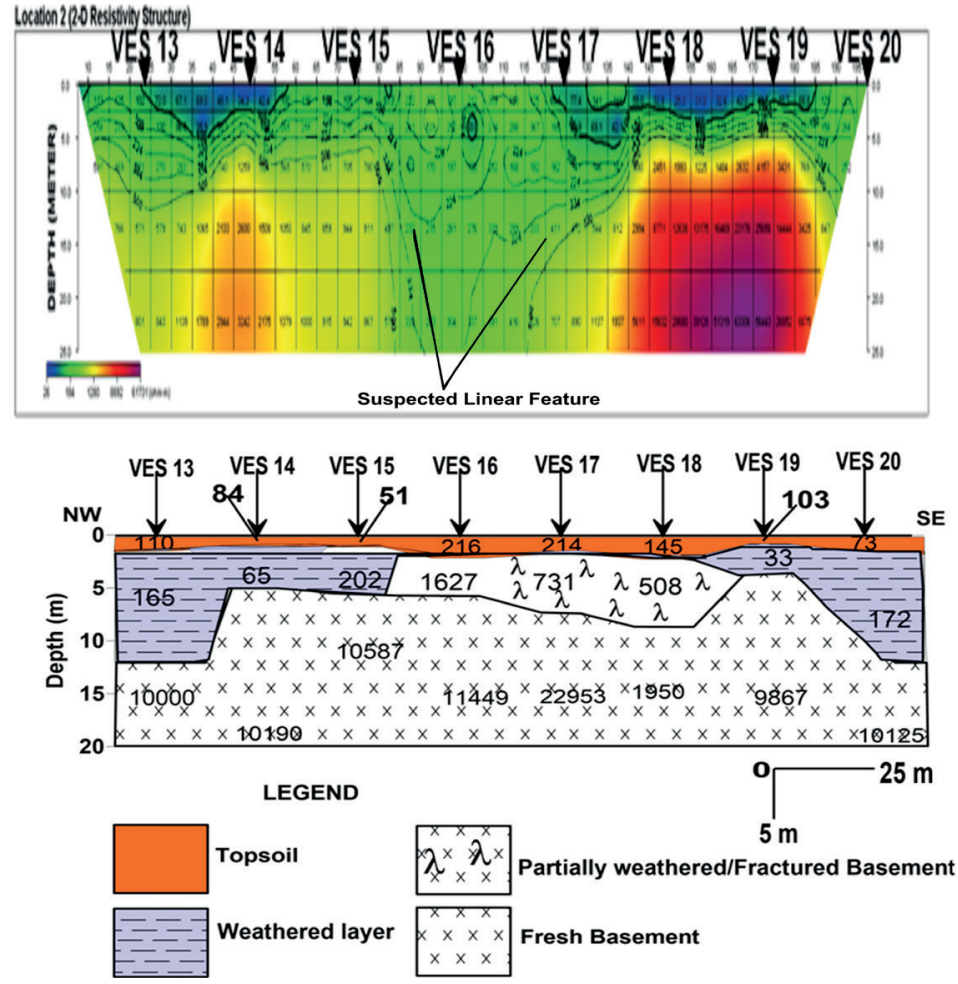

Fig. 6. VLF-EM 2-D inverted model (A); total magnetic field intensity profile (B); 2-D subsurface resistivity structure (C) and geoelectric section along failed section $2(D)$ 
The magnetic profile along this failed section shows an isolated magnetic low between distances 45-70 $\mathrm{m}$. Three major magnetic troughs were delineated along this section (Fig. 6B). The magnetic anomalies are located between $30-40 \mathrm{~m}, 45-70 \mathrm{~m}$, and $120-140 \mathrm{~m}$. These anomalies with considerable variations in magnetic field intensities identified at varying positions along the profile are characterized by peaks and troughs that are suspected to indicate magnetic sources in the subsurface (Reynolds 1997). These magnetic sources are related to lithological contacts or fractures/faults and other zones of weakness responsible for the failure of the road pavement. The 2-D dipole-dipole resistivity structure (Fig. 6C) displayed an isolated near-vertical low resistivity feature with a significant depth extent of up to $20 \mathrm{~m}$ typical of linear features such as faults and fractured zones or buried channel with surface expressions at distances 75-140 m. The failed section is underlain by four geological layers comprising the topsoil, the weathered layer, partially weathered/fractured basement, and the fresh basement (Fig. 6D). The topsoil has layer resistivity and thickness values varying between $73-216 \Omega \cdot \mathrm{m}$ and $0.8-2.0 \mathrm{~m}$, respectively, with corresponding mean values of $125 \Omega \cdot \mathrm{m}$ and $1.33 \mathrm{~m}$. These resistivity values correspond to clay, sandy clay to clayey sand. The road pavement is actually founded on subgrade soil characterized by very clayey materials and sandy clay in places, suggestive of weak zones that are capable of influencing the instability of the road. The weathered layer beneath the topsoil is characterized by resistivity values in the range 33-202 $\Omega \cdot m$ (Fig. 6D). The low resistivity values of this geoelectric layer correspond to clay, sandy clay, and clayey sand with the predominance of clay along the section. This clayey layer serves as poor engineering construction material (with resistivity value $<100 \Omega \cdot \mathrm{m}$ ), facilitating the failure witnessed along the road. These low resistivity values may be attributed to the water saturation of the weathered layer. The magnetic trough observed between distances 50-70 m correlates with a basement depression on the geoelectric section (Fig. 6D).

\section{Failed section 3}

The VLF-EM 2-D model shows relatively conductive features between $25-40 \mathrm{~m}, 60-85 \mathrm{~m}$, and $160-$ $200 \mathrm{~m}$ along the section (Fig. 7A). The identified high conductive medium can be indicative of geological features such as fractures and faults. A suspected confined basement fracture, which shows high conductivity along the road pavement as seen on the 2-D inversion model, falls within an intensively failed section of the road. The presence of the features characterized by negative current density (blue colour) ordinarily means resistive structure (Fig. 7A) except due to the length of the filter or by a decrease of current density due to the current gathering, which makes it not necessarily mean a resistive structure. The magnetic method presents the total magnetic field intensity profile along this failed section, and three major magnetic troughs are delineated (Fig. 7B). The magnetic anomalies are located between $25-75 \mathrm{~m}$, 110-130 $\mathrm{m}$, and 170-185 m. In addition, the total magnetic field shows a magnetic low between distances 130-160 m (Fig. 7B), possibly indicating a thin dyke (with a V shape structure) at this station. The 2-D dipole-dipole resistivity structure also shows that the overburden is generally thin $(<5 \mathrm{~m})$ in most places. There is no discernable structural feature on the 2-D resistivity structure (Fig. 7C). The failed section 3 is characterized by four geoelectric layers (Fig. 7D). These include the topsoil, the weathered layer, partially weathered/fractured basement, and fresh basement. The resistivity and thickness of the topsoil are 91-222 $\Omega \cdot \mathrm{m}$ and $0.6-1.3 \mathrm{~m}$, respectively. The corresponding mean values are $131 \Omega \cdot \mathrm{m}$ and $1.05 \mathrm{~m}$. The weathered layer resistivity values range $27-128 \Omega \cdot \mathrm{m}$. The thickness ranges $2.0-5.6 \mathrm{~m}$, with a mean value of $2.7 \mathrm{~m}$. The mean resistivity value of $62 \Omega \cdot \mathrm{m}$ was obtained for the weathered layer beneath the failed section, layer resistivity in the range $27-100 \Omega \cdot m$ which is an indication of very clayey materials characterize this layer (Fig. 7D). The partially weathered/fractured basement was delineated beneath VES points 21,27 , and 28 , corresponding to distances $25 \mathrm{~m}, 175 \mathrm{~m}$, and $200 \mathrm{~m}$, respectively, on the geoelectric section (Fig. 7D) with resistivity values of 481-904 $\Omega \cdot \mathrm{m}$. The presence of a fractured basement at a shallow depth may have also contributed to the failure of the section. There are also patches of resistive features between the distance of 75-125 m, which is an indication of basement intrusion on the geoelectric section (Fig. 7D). This section is characterized by 
the occurrence of a fresh basement at a very shallow depth. Hence, this section of the road should not ordinarily have failed had it not been for poor construction practice. It is also observed that the drainage provided have been totally blocked with sand sediments and waste materials as this has prevented the flowing of the runoff water from road cuts on both sides of the failed section, such that pools of water always accumulate at the road shoulders.
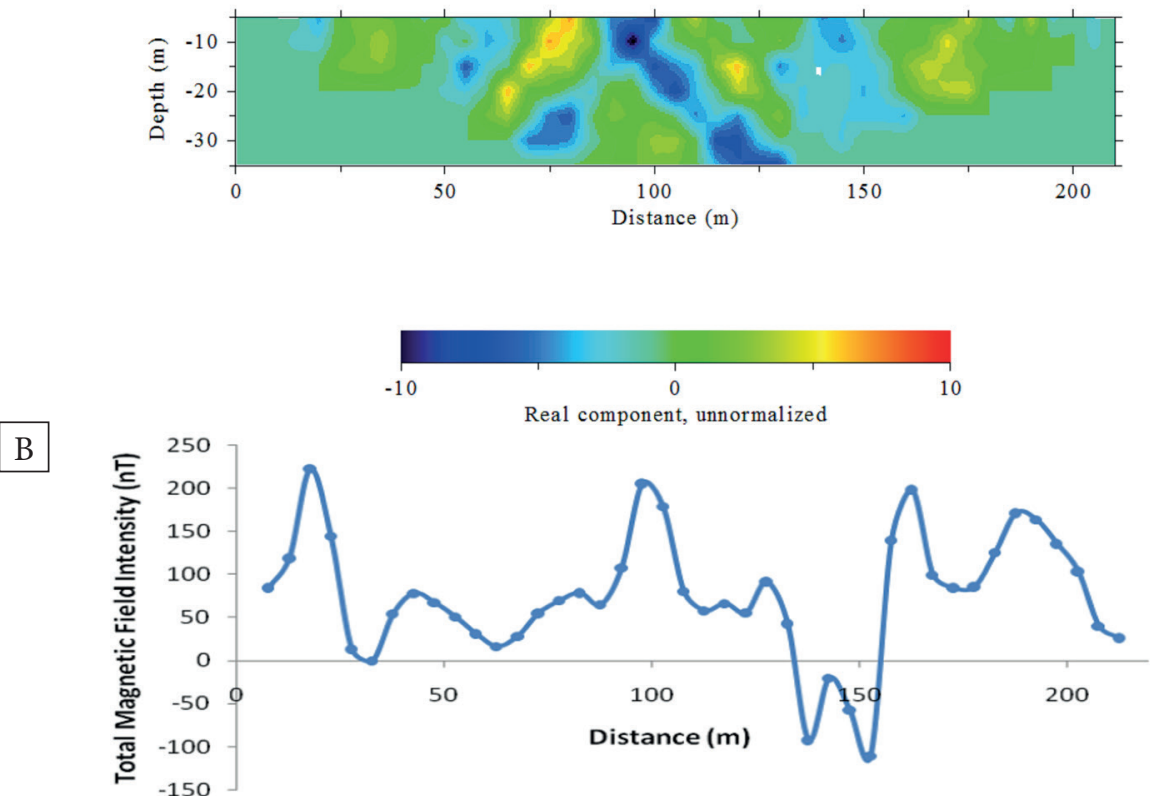

$\mathrm{C}$

Location 320.0Ressiscity Strocture)

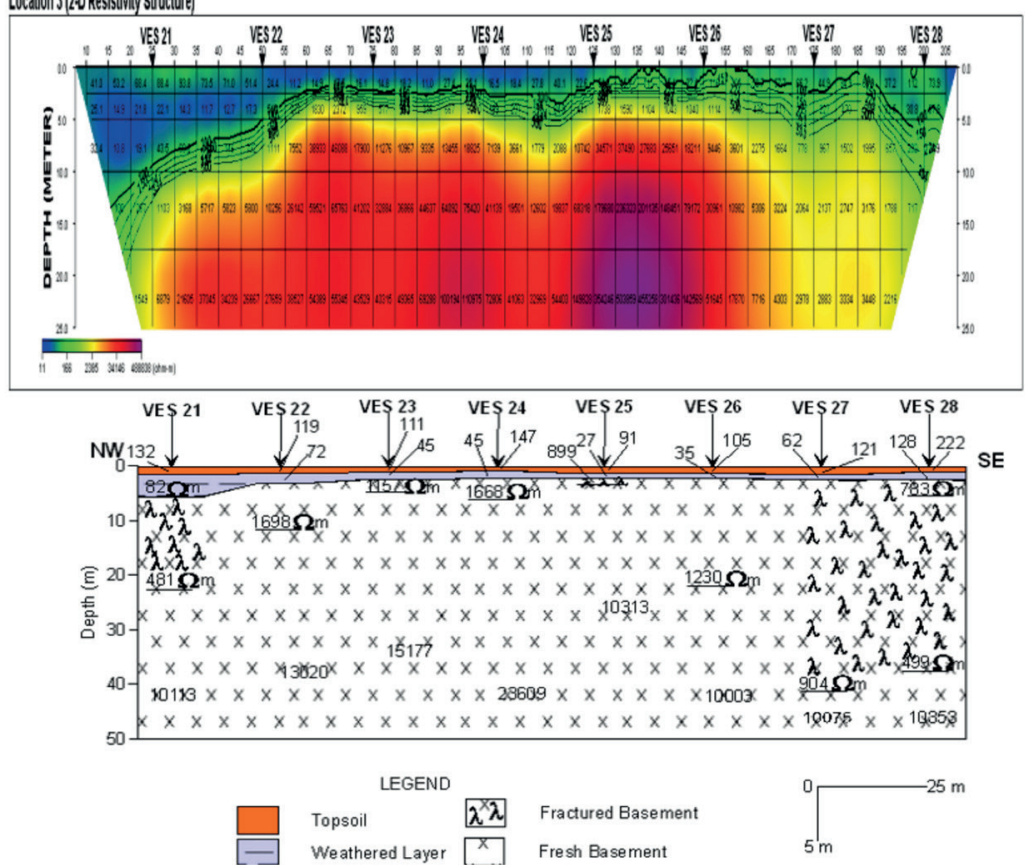

Fig. 7. VLF-EM 2-D inverted model (A); total magnetic field intensity profile (B); 2-D subsurface resistivity structure (C) and geoelectric section along failed section $3(D)$ 


\section{Failed section 4}

Failed section 4 shows anomalous VLF-EM signatures at various locations along the road segment. The 2-D model (Fig. 8A) shows patches of relatively conductive features between $15-35 \mathrm{~m}$, 50-120 $\mathrm{m}$, and $150-200 \mathrm{~m}$ along the failed section. These conductive zones are possible fractures/faults, aquiferous zones, or other weak zones in the form of clayey overburden beneath the subsurface. The magnetic profile along the failed section shows the major magnetic anomalies between $10-30 \mathrm{~m}$ and $45-55 \mathrm{~m}$.

$\mathrm{A}$

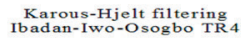
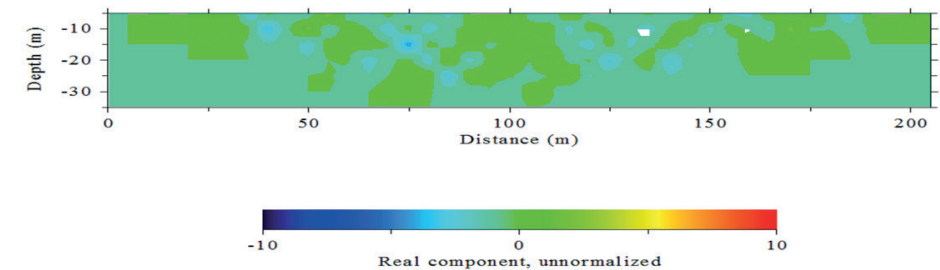

B

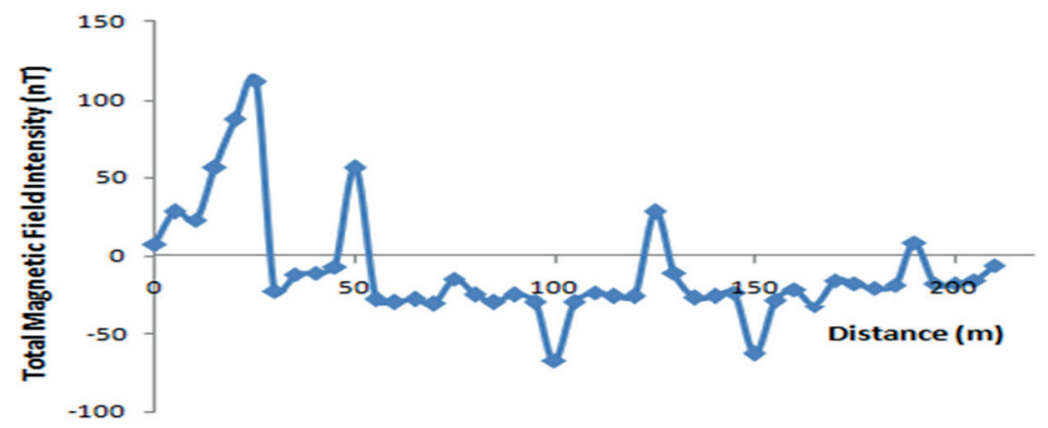

C

Location 420.0Resistity Structure)

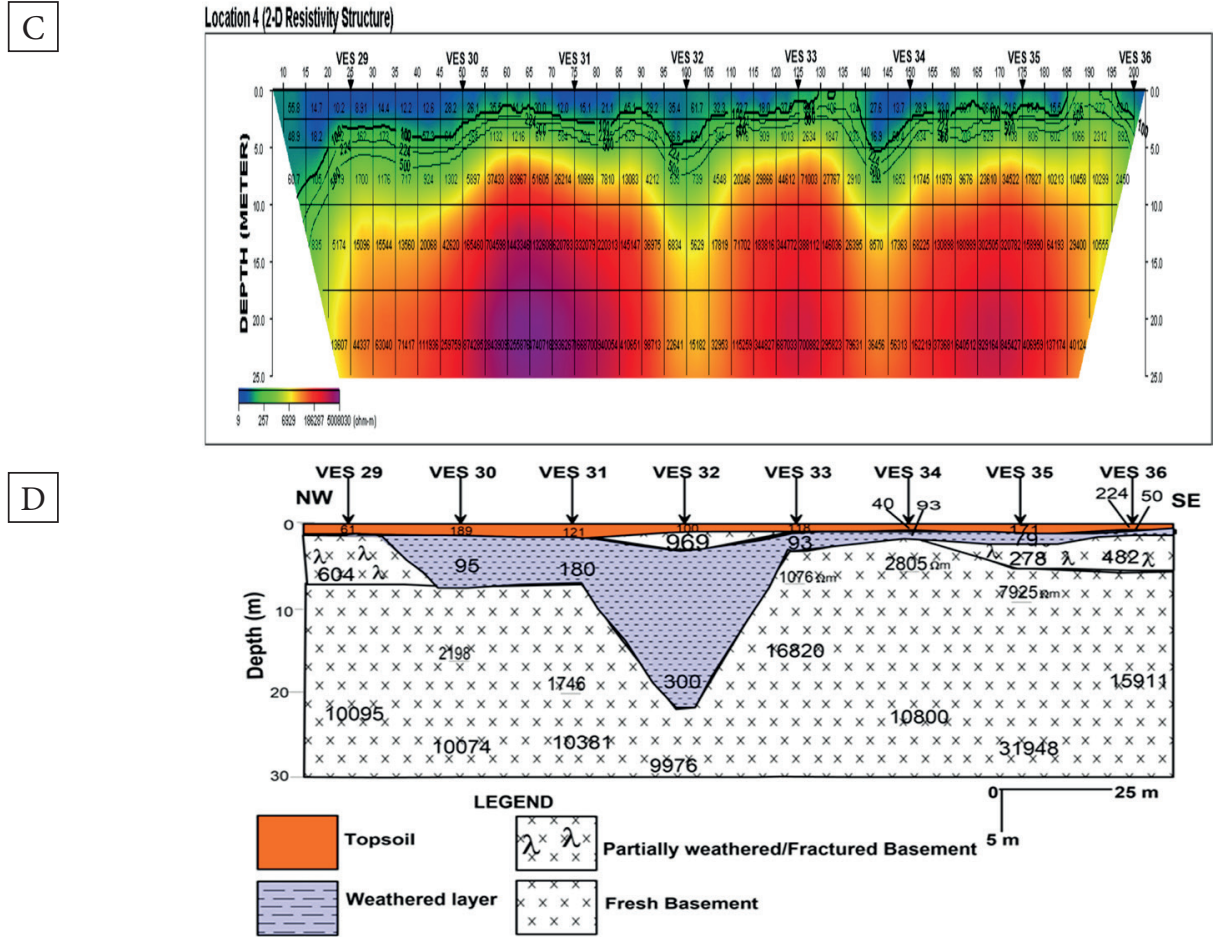

Fig. 8. VLF-EM 2-D inverted model (A); total magnetic field intensity profile (B); 2-D subsurface resistivity structure (C) and geoelectric section along failed section $4(D)$ 
Three major magnetic troughs were delineated along this section (Fig. 8B). The magnetic anomalies are located between $30-45 \mathrm{~m}, 55-125 \mathrm{~m}$, and 125-190 m. The magnetic anomaly zones correlate significantly with the VLF-EM anomalous zones along this section. The 2-D dipole-dipole resistivity structure (Fig. 8C) shows clayey overburden of the section. However, near-vertical/vertical low resistivity features having a depth extent of up to $10 \mathrm{~m}$ typical of lineaments/fractures with surface expressions at $95-110 \mathrm{~m}$ and $140-150 \mathrm{~m}$ of the section. These suspected geological structures are located within the failed section of the road and run across the highway. The failed section is characterized by four geoelectric layers; these include the topsoil, the weathered layer, the partially weathered layer, and the fresh basement. The resistivity value and thickness of the topsoil is 61-224 $\Omega \cdot \mathrm{m}$, and $0.7-1.4 \mathrm{~m}$, respectively. The corresponding mean values are $135 \Omega \cdot \mathrm{m}$ and $1.16 \mathrm{~m}$ that is characterized by clayey materials. The weathered layer is characterized by resistivity values in the range of $40-300 \Omega \cdot \mathrm{m}$. The low resistivity values of this geoelectric layer correspond to clay, sandy clay, and clayey sand with a depression (Fig. 8D). The partially weathered layer was delineated beneath VES points 29,35 , and 36 , corresponding to distances $0 \mathrm{~m}, 25 \mathrm{~m}, 175 \mathrm{~m}$, and $200 \mathrm{~m}$. The road pavement is founded on clayey subgrade soil at the southeastern flank with resistivity values generally less than $100 \Omega \cdot \mathrm{m}$. A suspected basement depression located beneath VES 32 corresponds to distance $100 \mathrm{~m}$ along the failed section on the geoelectric section (Fig. 8D). The magnetic low that exists within the region of $100 \mathrm{~m}$ correlates with a basement depression on the corresponding geoelectric section and the lineament/fracture with a surface expression at $100 \mathrm{~m}$ on the 2-D dipole-dipole model.

\section{Failed section 5}

The 2-D model (Fig. 9A) shows patches of conductive features between 0-100 m, 200-300 m, 400$500 \mathrm{~m}$, and 500-700 $\mathrm{m}$ from the Iwo-Osogbo end of failed section 5 . The suspected north dipping linear features are identified between $250-300 \mathrm{~m}$ and 400-500 $\mathrm{m}$ along the failed section. Three major magnetic troughs were delineated along this section (Fig. 9B). The magnetic anomalies are located between $50-100 \mathrm{~m}, 150-250 \mathrm{~m}$, and $270-700 \mathrm{~m}$.
The magnetic anomaly zones correlate significantly with the VLF-EM anomalous zones along this failed section. The 2-D dipole-dipole resistivity structure (Fig. 9C) displays a generally low resistivity overburden with isolated near-vertical low resistivity features with significant depth extent of up to $20 \mathrm{~m}$ or even greater in places, also, typical of linear features such as faults and fractured zones or buried channel with surface expressions at distances $85-110 \mathrm{~m}, 155-170 \mathrm{~m}, 225-250 \mathrm{~m}$, 375-425 m, 475-510 m, and 525-575 m. These suspected geological structures are located within the failed section of the road and run across the highway. Thick weathering depth typical of fractured or fissured zones within the basement rocks as displayed in the inverted resistivity structure (Fig. 9C). The failed section is underlain by five geological layers comprising the topsoil, laterite, the weathered layer, partially weathered/fractured basement, and the fresh basement (Fig. 9D). The topsoil has layer resistivity and thickness values varying between 101-350 $\Omega \cdot \mathrm{m}$ and $0.6-2.0 \mathrm{~m}$, respectively, with corresponding mean values of $182 \Omega \cdot \mathrm{m}$ and $1.36 \mathrm{~m}$. These resistivity values correspond to clayey sand and sandy clay. The lateritic layer underlies the VES 39, 42, 49, and 51 beneath the failed section. The weathered layer resistivity value varies $35-208 \Omega \cdot \mathrm{m}$ with $114 \Omega \cdot \mathrm{m}$ as the mean value. The corresponding thickness of this layer ranges $1.6-10.2 \mathrm{~m}$, with a mean value of $4.4 \mathrm{~m}$. The resistivity values indicate that this layer is predominantly composed of clay/sandy clay materials. The major part of the weathered layer is characterized by relatively low resistivity values $(<100 \Omega \cdot \mathrm{m})$ suggestive of weak zones and presence of clay enriched water-absorbing substratum that are capable of influencing the failure of the road. The partially weathered layer/fractured basement was delineated beneath VES points $40,44,46,48$, $52,53,56,57,58,59,60,61$, and 63 , corresponding to distances $100 \mathrm{~m}, 200 \mathrm{~m}, 250 \mathrm{~m}, 300 \mathrm{~m}, 400 \mathrm{~m}$, $425 \mathrm{~m}, 500 \mathrm{~m}, 525 \mathrm{~m}, 550 \mathrm{~m}, 575 \mathrm{~m}, 600 \mathrm{~m}, 625 \mathrm{~m}$, and $675 \mathrm{~m}$. The instability of the road pavement along the failed section of the road is precipitated by the presence of low resistive weathered layer materials and subsurface geological structures. The fresh basement constitutes the fifth layer with resistivity, and depth to bedrock values vary from $975 \Omega \cdot \mathrm{m}$ to infinity and $5.7-41.5 \mathrm{~m}$, respectively. 

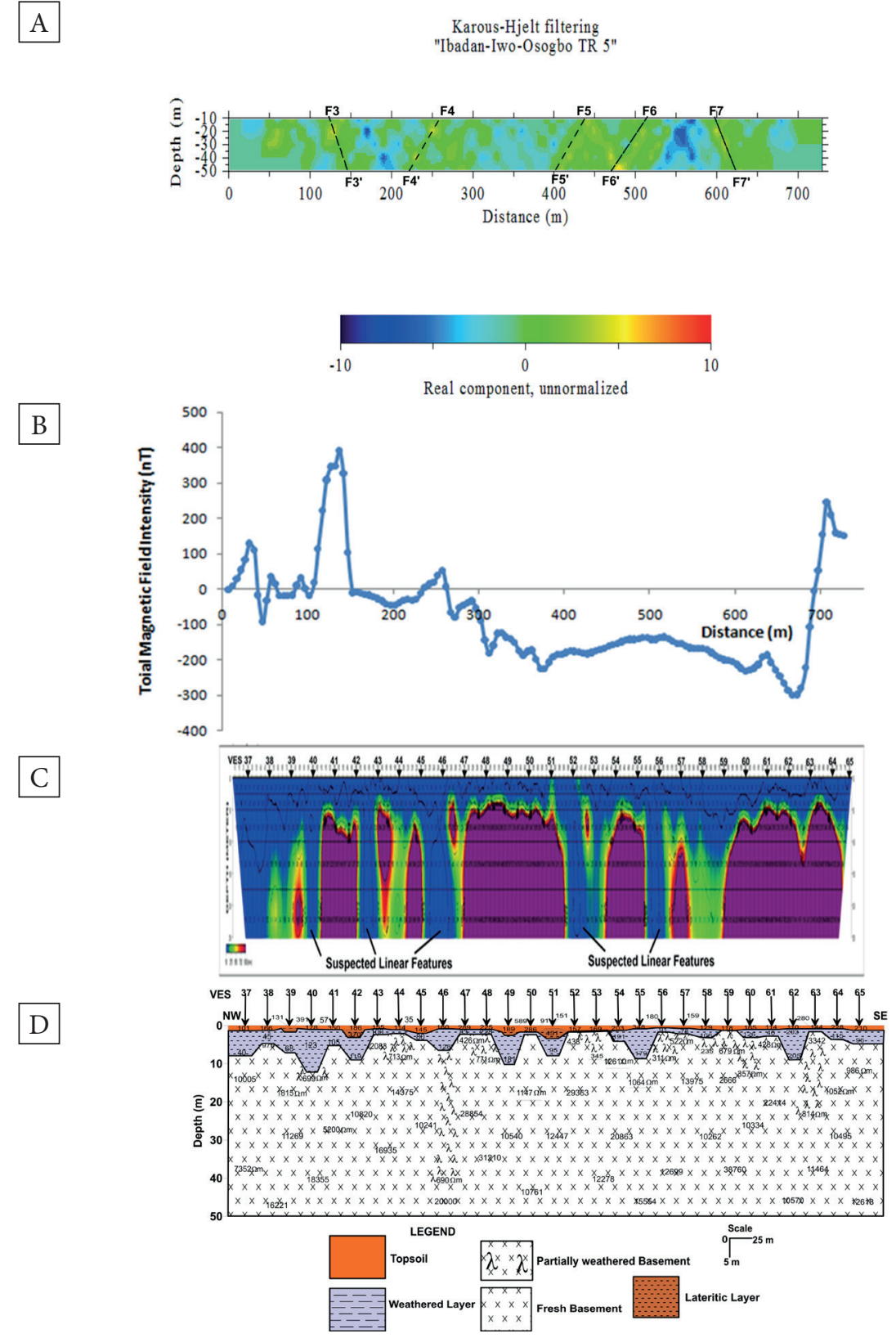

Fig. 9. VLF-EM 2-D inverted model (A); total magnetic field intensity profile (B); 2-D subsurface resistivity structure (C) and geoelectric section along failed section $5(D)$

\section{Failed section 6}

There exist different degrees of conductivities in the section (Fig. 10A). The presence of the conductive body is an indication of an incompetent layer across the road section. Magnetic troughs identified at around $90-150 \mathrm{~m}, 170-225 \mathrm{~m}$, and 250-275 m (Fig. 10B) may be due to near-surface effects. The magnetic anomalies observed were assumed to have resulted from the magnetic materials within the fractured/faulted zones. The 2-D dipole-dipole resistivity structure (Fig. 10C) display generally low resistivity overburden with isolated near-vertical low resistivity features with significant depth extent of up to $20 \mathrm{~m}$ or even greater in places, also typical of linear features suspected as fault/fractured zones, aquiferous zone or buried channel with surface expressions at distances $35-45 \mathrm{~m}, 85-105 \mathrm{~m}, 120-140 \mathrm{~m}$, and 
260-280 m. This may have accounted for the extremely bad condition of the failed section and may likely affect the neighbouring stable section. The failed section 6 is characterized by three geoelectric layers. These include the topsoil, the weathered layer, and the crystalline basement rock. The topsoil has resistivity values ranging between $117-475 \Omega \cdot \mathrm{m}$, and its thickness varies $0.8-1.5 \mathrm{~m}$. The corresponding mean values are $324 \Omega \cdot \mathrm{m}$ and $1.08 \mathrm{~m}$. These resistivity values correspond to clayey sand, sandy clay to laterite. The weathered layer beneath the topsoil is characterized by resistivity values that range $37-143 \Omega \cdot \mathrm{m}$ with the thickness in the range $2.2-5.7 \mathrm{~m}$. Mean resistivity value of $81 \Omega \cdot \mathrm{m}$ and mean thickness of $3.7 \mathrm{~m}$ was obtained for the weathered layer beneath the failed section, layer resistivity in the range of 37$100 \Omega \cdot \mathrm{m}$ which is indicative of very clayey materials (clay/sandy clay), commonly characterize this layer (Fig. 10D). There are indications of subsurface structural features within this failed section, as indicated on the 2-D resistivity structure. The low resistivity values of this geoelectric layer correspond to clay and clayey sand, where the clay is predominant along the section. The road pavement failure at this location may have been precipitated by a combination of incompetent clayey subsoil and a network of near-surface and subsurface linear features suspected to be lithological contact or fault/fracture zones.
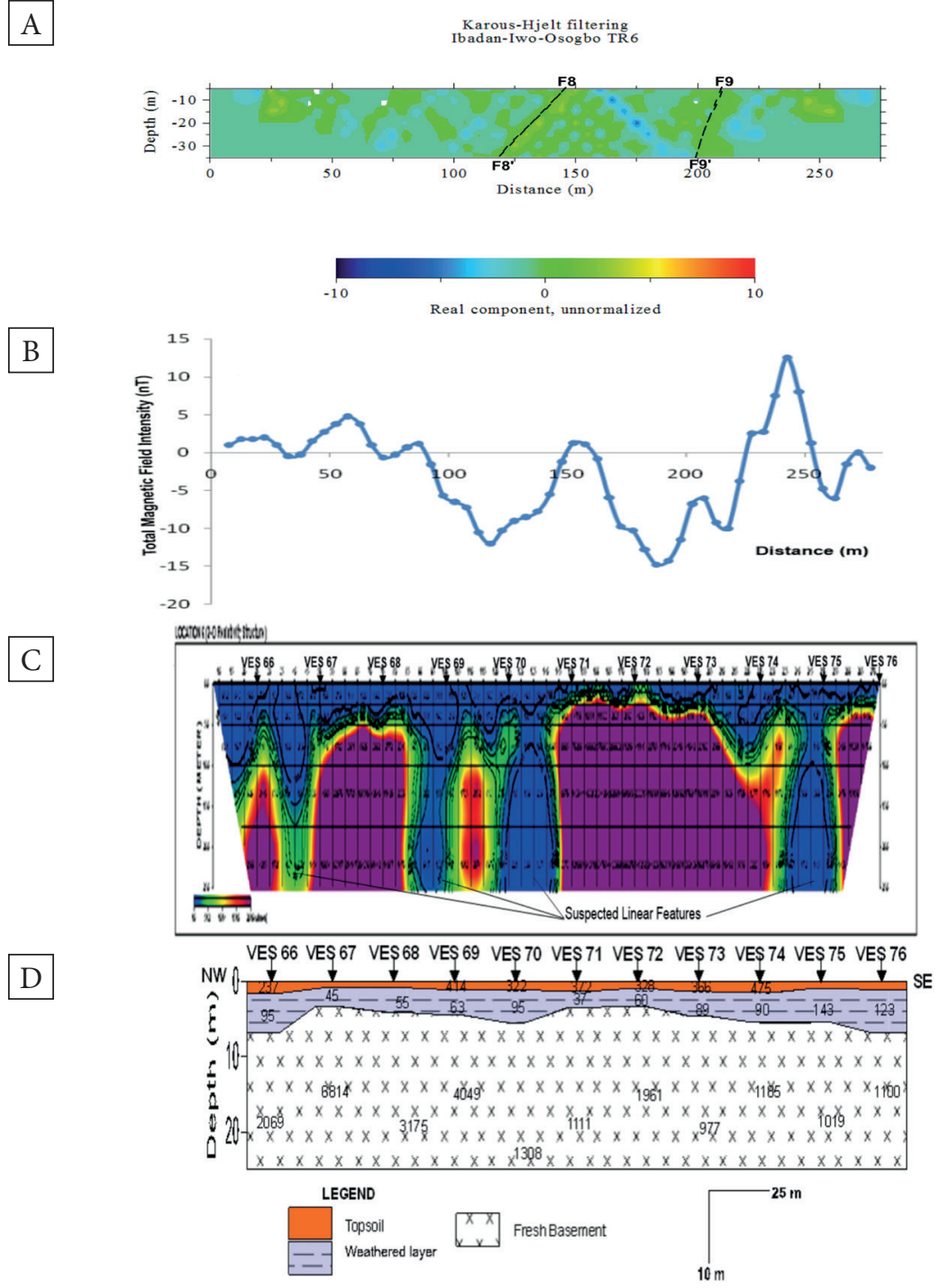

Fig. 10. VLF-EM 2-D inverted model (A); total magnetic field intensity profile (B); 2-D subsurface resistivity structure (C) and geoelectric section along failed section $6(D)$ 


\section{Stable section 1}

The 2-D inverted model shows that the study area is characterized by the existence of linear features of different conductivity ranges at distances between 35-175 m (Fig. 11A). The presence of the near-surface linear features such as faults and fractures are indicative of the weak geological formation upon which the road pavement was constructed, which could account for the failure of the road. The magnetic profile along the stable section is characterized by a relatively flat magnetic anomaly indicating a magnetically relatively homogeneous environment devoid of any significant structural feature (Fig. 11B) except between distances 0 and $90 \mathrm{~m}$, where the total magnetic field shows an isolated magnetic anomaly. One major magnetic trough was delineated along the stable section 1 between distances 50-75 m.
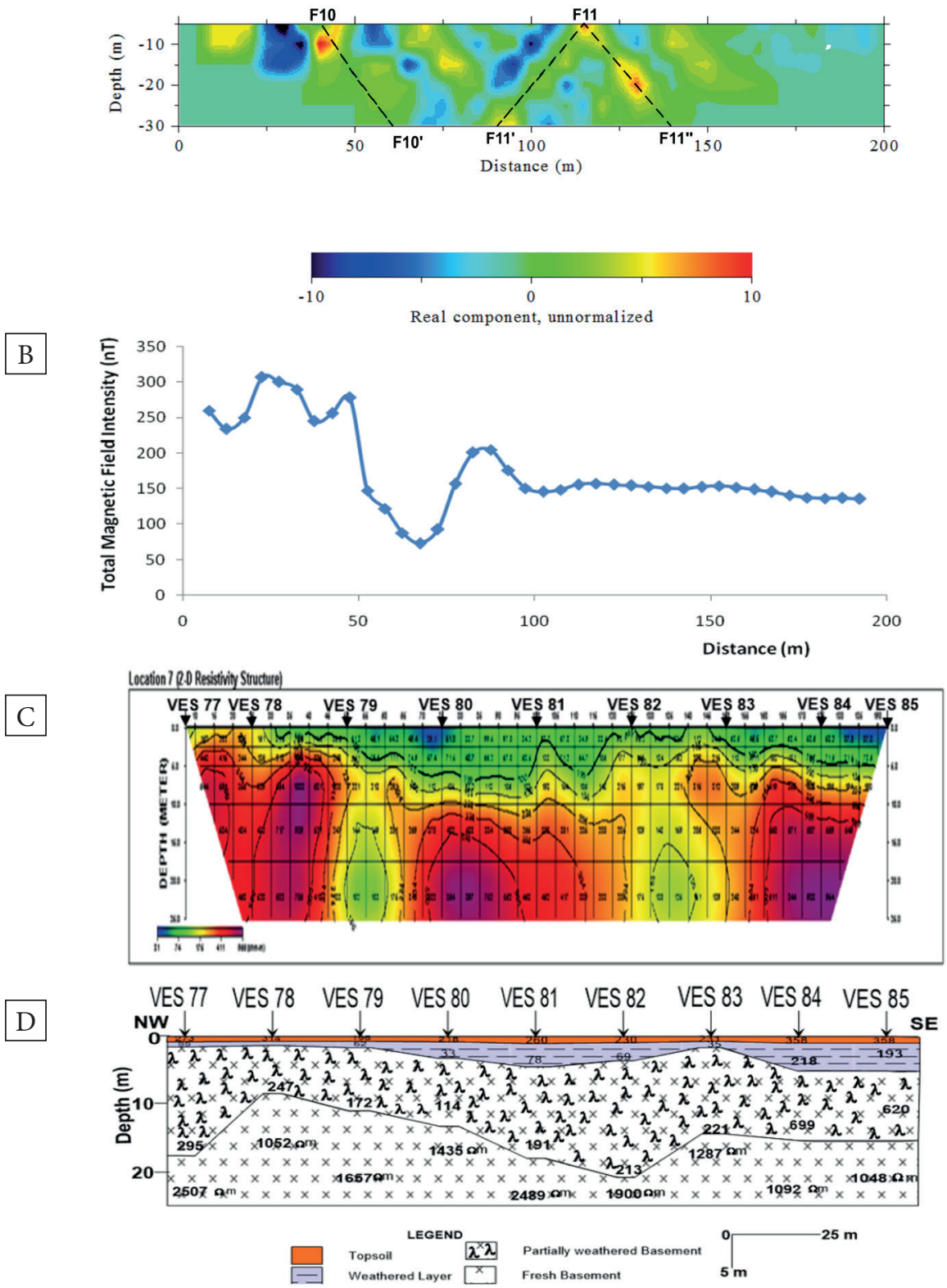

Fig. 11. VLF-EM 2-D inverted model (A); total magnetic field intensity profile (B); 2-D subsurface resistivity structure (C) and geoelectric section along stable section 1 (D) 
The 2-D dipole-dipole model (Fig. 11C) shows that there are indications of discontinuities located at distances between 50-60 $\mathrm{m}$ and 125$140 \mathrm{~m}$. This indicates that the section must have been a rehabilitated section. The stable section 1 is underlain by four subsurface layers composed of topsoil, weathered layer, partially weathered basement, and fresh basement. The road pavement is founded on resistive topsoil characterized by clayey sand to laterite with layer resistivity values ranging between 196-358 $\Omega \cdot \mathrm{m}$ with a thickness of $0.7-1.0 \mathrm{~m}$ (Fig. 11D). The weathered layer beneath the topsoil is characterized by resistivity values that range between $33-218 \Omega \cdot \mathrm{m}$, and its thickness varies $0.6-4.3 \mathrm{~m}$. The weathered layer is typically composed of clay, sandy clay, and clayey sand. In the northwestern flank, this section is characterized by low resistivity $(<100 \Omega \cdot \mathrm{m})$ substratum, which is indicative of clay materials that are not suitable for road pavement. The partially weathered/fractured basement has resistivity values varying between 114-699 $\Omega \cdot \mathrm{m}$ (Fig. 11D). These resistivity values correspond to water-bearing fractured basement/aquiferous zone beneath the subsurface that could also contribute to the failure of the road pavement in the future. The basement bedrock relief of the geoelectric section (Fig. 11D) also confirms the VLF-EM inverted model (Fig. 11A) and the 2-D resistivity structure that identified significant linear geological features. This section of the road shows no signs of distress, despite the low resistivity substratum beneath the road pavement. The stability of the road pavement may be due to the good construction materials used or recent rehabilitation works on the road. The section of the road is very likely to fail in the future due to the presence of low resistivity water-absorbing clay beneath the pavement.

\section{Stable section 2}

There are features of different degrees of conductivities in the section. The presence of high conductive zones at various points is indicative of a weak/ incompetent layer across the road section. The linear features observed display high conductivity on the VLF-EM section at distances between 60 $80 \mathrm{~m}$ and $100-175 \mathrm{~m}$ suspected geological features such as faults or fractures (Fig. 12A). The magnetic profile along this stable section shows three magnetic troughs (Fig. 12B). The magnetic anomalies are located between $25-35 \mathrm{~m}, 60-70 \mathrm{~m}$, and 110-125 m. The 2-D resistivity structure generally revealed high resistivity values at many station points above a depth of $30 \mathrm{~m}$ (Fig. 12C). It shows no evidence of subsurface geological structures that could precipitate the failure of the road. This confirms the field observation, as no sign of distress was noticed in this section of the road in this locality. Four subsurface layers are delineated at this study location; the topsoil, lateritic layer, weathered layer, and fresh basement (Fig. 12D). The resistive topsoil is composed of sand/lateritic sand with resistivity variation of 261-616 $\Omega \cdot \mathrm{m}$ and a thickness of $0.7-1.3 \mathrm{~m}$. The lithological unit beneath the topsoil is a lateritic layer with resistivity values varying between $240-660 \Omega \cdot \mathrm{m}$ and the thickness varying between $1.3-9.9 \mathrm{~m}$. The underlying weathered layer is composed of sand with resistivity values ranging $205-630 \Omega \cdot m$ and a thickness variation of 8.4-24.4 m (Fig. 12D). The presence of the lateritic layer and high resistive topsoil accounts for the stability of the road pavement at this locality. The high resistivity of the weathered layer substratum is due to the nature of rock type (pegmatite) in the area. Thus, the geological condition of an area is a key factor for the stability of roads. The fresh basement with resistivity values varying between $929-7725 \Omega \cdot \mathrm{m}$, and the depth to bedrock varies 3.8-24.4 m (Fig. 12D). The results show that the unstable sections of the highway are composed of clay, which is not suitable for a road pavement at a shallower depth than the stable section. The basement relief of the geoelectric section (Fig. 12D) confirms the 2-D resistivity structure that is devoid of significant linear features which are indications of a near homogeneous subsurface sequence. The road pavement is founded on the topsoil and laterite with layer resistivity values ranging between $240-660 \Omega \cdot \mathrm{m}$. VES curves are all with increasing competence with depth. The topsoil and the laterite are composed of relatively high resistivity values generally greater than $200 \Omega \cdot m$, thick enough to support the imposed wheel load. Highway pavement stability at this locality is as a result of the competent resistive subsoil upon which the road pavement is constructed. 
A

Karous-Hjelt filtering "Ibadan-Iwo-Osogbo S S $2 "$
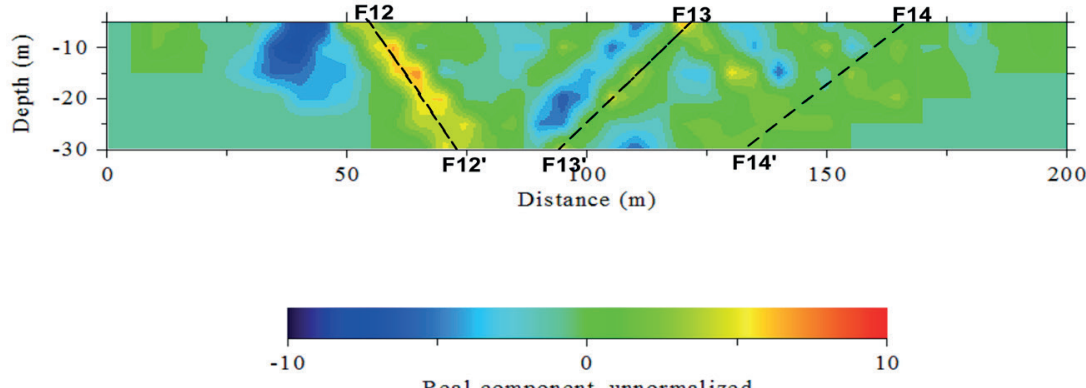

B 틀

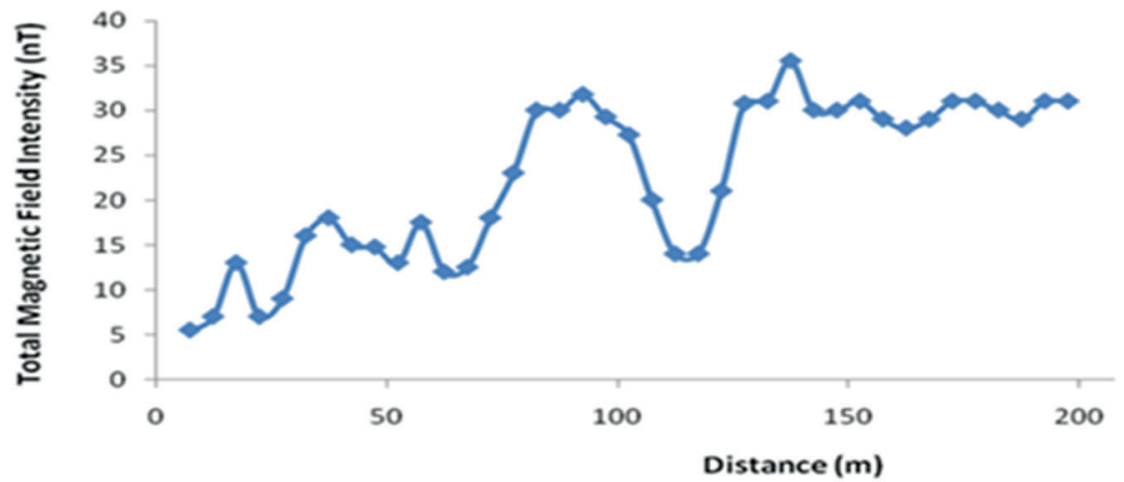

C

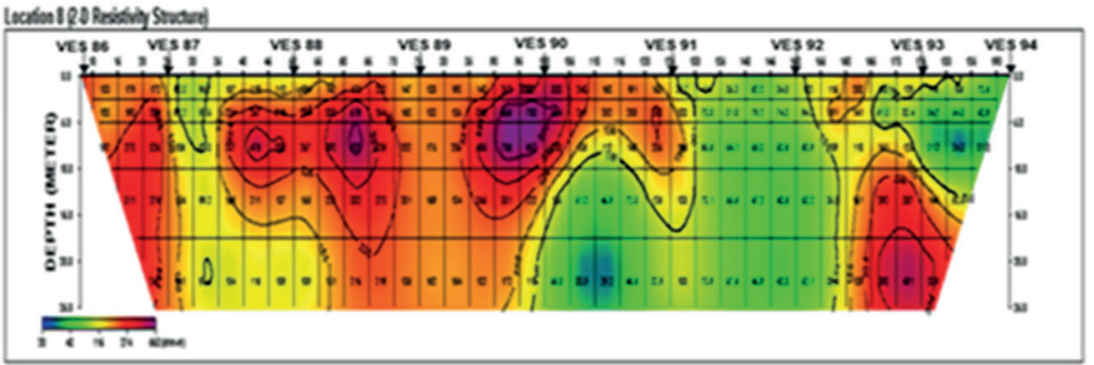

$\mathrm{D}$

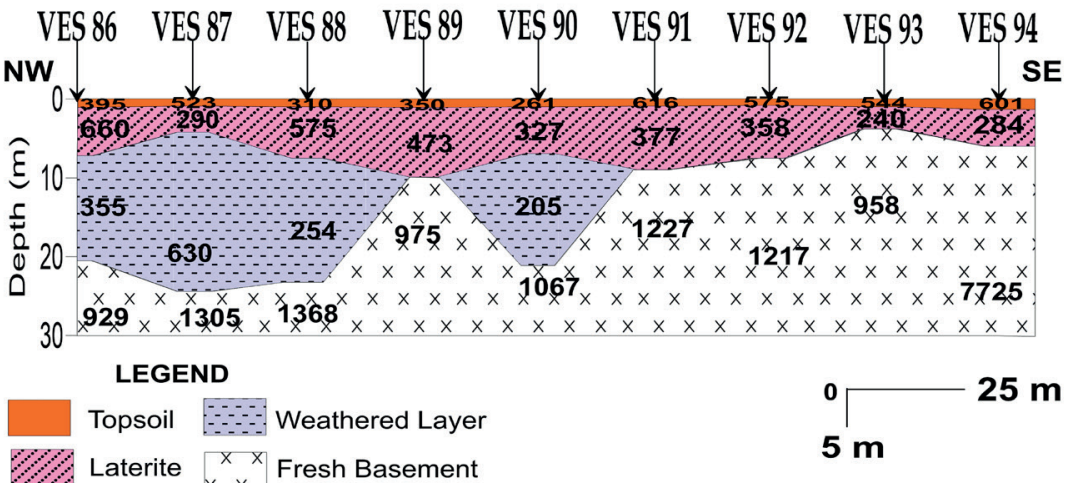

Fig. 12. VLF-EM 2-D inverted model (A); total magnetic field intensity profile (B); 2-D subsurface resistivity structure (C) and geoelectric section along stable section 2 (D)

A combined view of the results showed that the instability of the road pavement along the failed sections of the road is precipitated by the presence of low resistive weathered layer materials
(Tab. 2), subsurface geological structures, a relatively shallow water table, poor construction practices and the absence of a drainage network for runoff in the area. 
Table 2

Total magnetic field, VLF-EM responses and resistivity values of the subsurface layers of the study area

\begin{tabular}{|c|c|c|c|c|c|c|c|c|}
\hline \multirow[b]{2}{*}{$\begin{array}{l}\text { Loca- } \\
\text { tion }\end{array}$} & \multirow[b]{2}{*}{$\begin{array}{c}\text { Total } \\
\text { magnetic } \\
\text { field range } \\
{[\mathrm{nT}]}\end{array}$} & \multicolumn{2}{|c|}{ VLF-EM responses } & \multicolumn{5}{|c|}{ Resistivity range $[\Omega \cdot \mathrm{m}]$} \\
\hline & & $\begin{array}{c}\text { Raw } \\
\text { real range } \\
{[\%]}\end{array}$ & $\begin{array}{c}\text { Filtered } \\
\text { real range } \\
{[\%]}\end{array}$ & Topsoil & $\begin{array}{c}\text { Lateritic } \\
\text { layer }\end{array}$ & $\begin{array}{c}\text { Weath- } \\
\text { ered } \\
\text { layer }\end{array}$ & $\begin{array}{c}\text { Partially } \\
\text { weathered/ } \\
\text { fractured } \\
\text { basement }\end{array}$ & $\begin{array}{c}\text { Fresh } \\
\text { basement }\end{array}$ \\
\hline FS 1 & $-251-464$ & $-13.0-18.0$ & $-16.0-17.0$ & $20-224$ & 799 & $11-38$ & $564-937$ & $1198-14744$ \\
\hline FS 2 & $-208-213$ & $-6.1-6.1$ & $-9.4-6.3$ & $51-216$ & - & $33-202$ & $508-731$ & $1627-22953$ \\
\hline FS 3 & $-111-223$ & $-11.9-13.4$ & $-11.9-14.6$ & $91-222$ & - & $27-128$ & $481-904$ & $1157-28609$ \\
\hline FS 4 & $-49-33$ & $-3.7-5.7$ & $-4.4-5.4$ & $61-224$ & - & $40-300$ & $278-969$ & $1076-31948$ \\
\hline FS 5 & $-301-391$ & $-8.6-7.9$ & $-7.4-5.0$ & $101-350$ & $370-589$ & $35-280$ & $235-814$ & $975-31210$ \\
\hline FS 6 & $-15-13$ & $-5.1-6.4$ & $-4.6-6.3$ & $117-475$ & - & $37-143$ & - & $977-6814$ \\
\hline SS 1 & $73-307$ & $-11.8-12.8$ & $-18.5-29.3$ & $196-358$ & - & $33-218$ & $114-699$ & $1048-2507$ \\
\hline SS 2 & $6-36$ & $-11.9-5.6$ & $-13.1-6.9$ & $261-616$ & $240-660$ & $205-630$ & - & $929-7725$ \\
\hline
\end{tabular}

The stable control sections have the following characteristics:

- The road pavements are founded on topsoil/ subsoil with moderate to high layer resistivity values greater than $195 \Omega \cdot \mathrm{m}$, which are clayey sand in composition (Tab. 2).

- The sections are generally devoid of linear geological features such as fractures, faults, lithological contact, and depressions, which are zones of weakness that may increase porosity and fluid permeability of subsoil and decrease the load-bearing capacity of the road pavement.

From the engineering subsurface evaluation of the study area, the failed sections of the road are underlain by schist-pegmatitised, variably migmatised gneiss, coarse-porphyritic biotite, and biotite-muscovite granite. The rock types are susceptible to weathering and can weather into clay materials (sandy clay and clayey sand). The relatively high resistivity values of the topsoil of some failed sections may be a result of rock boulders/ rock fragment (sandstone/gravel/granite) used during previous maintenance and reconstruction works. The subgrade soil beneath the failed sections of the highway is generally clayey with low resistivity values $(<100 \Omega \cdot \mathrm{m})$. Stable section 1 is underlain by the same geological rock types as in the failed sections. Stable section 2 is underlain by pegmatite and fine-medium grained granite. Pegmatite is a strong rock type that weathers into residual soil (gravel/laterite). Fine-medium grained granite is one of the most suitable rocks proven as road and building stones because of their low water absorption, low flakiness and elongation indices, low abrasion values, higher strength and sound petrographic characters (Ademila 2019). The topsoil is highly resistive, and subgrade soil is lateritic with a significant thickness capable of withstanding the traffic load stress imposed. The stable section is due to the presence of laterite, which may have formed through the oxidation of clay exposed to the surface, becomes hard solid outcrops along the road section. Also, the section is stable due to the use of good and competent construction materials.

\section{CONCLUSION}

Land satellite imagery and integrated geophysical methods have been used in establishing that geological factors have contributed to the continuous failure of the highway. The highway pavement instability can be attributed to the existence of near-surface linear geological features such as fractures, faults, aquiferous zones or buried stream channels, bedrock depressions, and lithological contacts beneath the highway pavements which are structurally weak zones that enhance the accumulation of water. The incompetent water-absorbing clayey nature of the topsoil, which constitutes the subgrade upon which the road is constructed, collapses under the vehicular loads imposed. Also, the presence of a fractured 
basement at a shallow depth influences the instability of the highway pavement. The relatively shallow water table in the area, coupled with poor construction practice due to the absence of a drainage network for runoff water flowing from road cuts on both sides of the failed sections, precipitated the failure of the highway. Thus, the design and construction of a road should not be concluded without a considerable amount of geological information of the subsurface structures caused by the geophysical anomalies. It therefore becomes imperative that geological factors are properly investigated before any road construction for sustainable development to maximize social and economic benefits, reduce financial losses associated with road maintenance, rehabilitation, and reconstruction of failed roads. The results of the magnetic, electromagnetic and electrical resistivity methods have effectively provided the detailed subsurface geological information and lithological setting within the area vital for the successful and safe reconstruction of the highway to ensure its stability. As a result, this study advises the government, civil engineers, and societies on the need to create environmental awareness on the importance of subsoil investigation prior to road construction. Thus, these integrated geophysical techniques are invaluable non-destructive tools for pre-construction and post-construction engineering investigations to avert possible structural failure for successful and sustainable construction works.

\section{REFERENCES}

Ademila O., 2015. Integrated geophysical survey for post foundation studies in a typical Basement Complex of Southwestern Nigeria. The Pacific Journal of Science and Technology, 16, 2, 274-285

Ademila O., 2017. Engineering geophysical investigation of some unstable sections of Ibadan-Iwo-Osogbo Highway, Southwestern Nigeria. University of Ibadan, Ibadan, Nigeria [unpublished $\mathrm{PhD}$ thesis].

Ademila O., 2019. Engineering geological evaluation of some rocks from Akure, Southwestern Nigeria as aggregates for concrete and pavement construction. Geology, Geophysics and Environment, 45, 1, 31-43.

African Development Bank, 2003. Review of the implementation status of the Trans African highways and missing links. Main report, 1, 58.

Ajibade A.C. \& Fitches W.R., 1988. The Nigerian Precambrian and the Pan African Orogeny. [in:] Oluyide P.O., Mbonu W.C., Ogezi A.E.O., Egbuniwe I.G., Ajibade A.C. \& Umeji A.C. (eds.), Precambrian Geology of Nigeria, Geological Survey of Nigeria, 45-53.
Annor A.E., 1995. U-Pb-Zr age for Kabba-Okene granodiorite gneiss; Implication for Nigeria's basement chronology. Africa Geosciences Review, 2, 101-105.

Dipro for Windows, 2001. DiproTM Version 4.01, Processing and Interpretation Software for Electrical Resistivity Data. Korea Institute of Geosciences and Mineral Resources (KIGAM), Daejon, South Korea.

Guardian News Paper, 2012. Road accidents on the rise. Federal Road Safety Commission (FRSC) gives ultimatum. The Guardian, August 1, 7.

Kadhim N., Mourshed M. \& Bray M., 2016. Advances in remote sensing applications for urban sustainability. Euro-Mediterranean Journal for Environmental Integration, 1, 7.

Karous M.R. \& Hjelt S.E., 1983. Linear filtering of VLF dip angle measurements. Geophysical Prospecting, 31, 782-794.

Kavak K.S. \& Cetin H., 2007. A detailed geological lineament analysis using Landsat TM data of Golmarmara/ Manisa Region, Turkey. Online Journal of Earth Sciences, $1,3,145-153$.

Nelson R.G. \& Haigh J.H., 1990. Geophysical investigation of lateritic terrain. [in:] Ward S.H. (ed.), Geotechnical and Environmental Geophysics, Geotechnical, Vol. 2, Society of Exploration Geophysicist, Tulsa, 133-154.

Nigeria Geological Survey Agency, 2009. Geological map of Ibadan and Iwo areas. Geological Survey of Nigeria.

Olayinka A.I., Abimbola A.F., Isibor R.A. \& Rafiu A.R., 1999. A geoelectrical-hydrochemical investigation of shallow groundwater occurrence in Ibadan, Southwestern Nigeria. Environmental Geology, 37, 1\&2, 31-39.

Olayinka A.I., Oladunjoye M.A., Osinowo O.O. \& Adeyemi G.O., 2007. Integrated geophysical investigation to determine causes of structural failures at a factory site in Benin City, Nigeria. [in:] London 2007: securing the future: 69th EAGE Conference \& Exhibition incorporating SPE EUROPEC 2007, 11-14 June 2007, ExCeL, London, EAGE, Houten, 11-14.

Olayinka A.I. \& Olayiwola M.A., 2001. An integrated use of geoelectrical imaging and hydrogeochemical methods in delineating limits of polluted surface and groundwater at a landfill site in Ibadan area, southwestern Nigeria. Journal of Mining and Geology, 37, 1, 53-68.

Olorunfemi M.O., Inumidun B.I., Gabriel O.B. \& Akintorinwa J.O., 2010. Micro-resistivity measurements, near-surface sequence delineation and empirical relationship with engineering geotechnical parameters. The Pacific Journal of Science and Technology, 11, 1, 537-544.

Oluwafemi O., 2012. Electrical Resistivity Imaging Survey for Shallow Site Investigation at University of Ibadan Campus, Southwestern Nigeria. Asian Research Publishing Network (ARPN) Journal of Engineering and Applied Sciences, 7, 2, 1-10.

Oyawoye M.O., 1972. The basement complex of Nigeria. [in:] Dessanvagie T.F.J. \& Whiteman A.J. (eds.), African Geology, Ibadan University Press, 67-99.

Oyinloye A.O., 2011. Geology and geotectonic setting of the Basement Complex rocks in Southwestern Nigeria: Implications on provenance and evolution. [in:] Dar I.A. \& Dar M.A., Earth and Environmental Sciences, InTech, 98-117.

Pirttijärvi M., 2004. KH filt program. A geophysical software for Karous-Hjelt and Fraser Filtering on Geophysical VLF (very low frequency) Data. Geophysical Division, Department of Geosciences, University of Oulu, Finland. 
Rahaman M.A., 1981. Recent Advances in the Study of the Basement Complex of Nigeria. [in:] The Precambrian Geology of Nigeria: (Proceedings of the First Symposium on the Precambrian Geology of Nigeria Organized by the Geological Survey of Nigeria, Under the Auspices of the Federal Ministry of Mines and Power, from 14th to October 17, 1981 at Durbar Hotel, Kaduna, Geological Survey of Nigeria, 11-43.

Reynolds J.M., 1997. An introduction to Applied and Environmental Geophysics. John Wiley and Sons, Chichester.

Schnebele E., Tanyu B.F., Cervone G. \& Waters N., 2015. Review of remote sensing methodologies for pavement management and assessment. European Transportation Research Review, 7, 7, 1-19.
Sharma P.V., 1997. Environmental and Engineering Geophysics. Cambridge University Press, Cambridge.

Vander Velper B.P.A., 2004. WinResist Version 1.0 Resistivity Depth Sounding Interpretation Software. ITC, Delft, Netherland [MSc research project].

Viljoen R.P., Viljoen M.J., Grootenboer J. \& Longshaw T.G., 1983. ERTS-1 imagery: an appraisal of applications in Geology and mineral exploration. [in:] Watson K. \& Regan R.D. (eds.), Remote Sensing, Geophysics Reprint Series No. 3, Society of Exploration Geophysicist, 58-92.

Woakes M., Ajibade C.A. \& Rahaman M.A., 1987. Some metallogenic features of the Nigerian Basement. Journal of Africa Science, 5, 655-664 